\title{
Oblique rifting: the rule, not the exception
}

\author{
Sascha Brune $^{1,2}$, Simon E. Williams ${ }^{3}$, and R. Dietmar Müller ${ }^{3,4}$ \\ ${ }^{1}$ GFZ German Research Centre for Geosciences, 14473 Potsdam, Germany \\ ${ }^{2}$ Institute of Earth and Environmental Science, University of Potsdam, 14476 Potsdam-Golm, Germany \\ ${ }^{3}$ EarthByte Group, School of Geosciences, University of Sydney, Sydney, New South Wales 2006, Australia \\ ${ }^{4}$ Sydney Informatics Hub, University of Sydney, Sydney, New South Wales, Australia
}

Correspondence: Sascha Brune (brune@gfz-potsdam.de)

Received: 3 July 2018 - Discussion started: 16 July 2018

Revised: 12 October 2018 - Accepted: 15 October 2018 - Published: 26 October 2018

\begin{abstract}
Movements of tectonic plates often induce oblique deformation at divergent plate boundaries. This is in striking contrast with traditional conceptual models of rifting and rifted margin formation, which often assume 2-D deformation where the rift velocity is oriented perpendicular to the plate boundary. Here we quantify the validity of this assumption by analysing the kinematics of major continent-scale rift systems in a global plate tectonic reconstruction from the onset of Pangea breakup until the present day. We evaluate rift obliquity by joint examination of relative extension velocity and local rift trend using the script-based plate reconstruction software pyGPlates. Our results show that the global mean rift obliquity since $230 \mathrm{Ma}$ amounts to $34^{\circ}$ with a standard deviation of $24^{\circ}$, using the convention that the angle of obliquity is spanned by extension direction and rift trend normal. We find that more than $\sim 70 \%$ of all rift segments exceeded an obliquity of $20^{\circ}$ demonstrating that oblique rifting should be considered the rule, not the exception. In many cases, rift obliquity and extension velocity increase during rift evolution (e.g. Australia-Antarctica, Gulf of California, South Atlantic, India-Antarctica), which suggests an underlying geodynamic correlation via obliquity-dependent rift strength. Oblique rifting produces 3-D stress and strain fields that cannot be accounted for in simplified 2-D plane strain analysis. We therefore highlight the importance of 3-D approaches in modelling, surveying, and interpretation of most rift segments on Earth where oblique rifting is the dominant mode of deformation.
\end{abstract}

\section{Introduction}

The relative motion of Earth's tectonic plates often causes oblique deformation at divergent plate boundaries. This is primarily due to the fact that irregularly shaped plate boundaries generally do not align with small-circles of relative plate movement and that changes in plate motion additionally lead to time-dependent plate boundary obliquity (DíazAzpiroz et al., 2016; Philippon and Corti, 2016). Traditionally, rift evolution and passive margin formation have been investigated using 2-D conceptual and numerical models assuming an alignment of relative plate motion and plate boundary normal. These studies yielded major insights into first-order subsidence patterns (McKenzie, 1978; White, 1993), described key phases controlling the architecture of rifted margins (Lavier and Manatschal, 2006; Huismans and Beaumont, 2011; Brune et al., 2016) and provided insight into the fault evolution during rifting (Ranero and PérezGussinyé, 2010; Brune et al., 2014; Bayrakci et al., 2016; Naliboff et al., 2017). The applicability of these concepts and models is often rooted in the assumption that rifts can be understood via plane strain cross sections orthogonal to the rift trend and that the direction of extension aligns with the orientation of these cross sections. Many rifts and passive margins, however, involve segments where the extension direction is not perpendicular to the rift strike such that oblique, nonplane strain configurations occur (Sanderson and Marchini, 1984; Dewey et al., 1998).

Oblique rift segments differ from classical orthogonal examples in several major aspects:

1. In contrast to orthogonal rifts, the initial phase of oblique rifting is characterized by segmented en éche- 
lon border faults that strike at an angle to the rift trend. The orientation of these faults is controlled by the interplay of inherited heterogeneities with far-field stresses, whereas diverse modelling studies independently suggest a fault orientation that lies in the middle between the rift trend and the extension-orthogonal direction (Withjack and Jamison, 1986; Clifton et al., 2000; Corti, 2008; Agostini et al., 2009; Brune and Autin, 2013). These large en échelon faults generate pronounced relay structures (Fossen and Rotevatn, 2016) which act as a major control on fluvial sediment transport (Gawthorpe and Leeder, 2000).

2. Seismic cross sections at rifted margins are often taken perpendicular to the rift trend, which in most cases is also perpendicular to the coastline. Considering that faults in oblique rifts do not strike parallel to the rift trend, seismic profiles will observe a projection of the fault surface that features a smaller dip angle than the actual 3-D fault, an error that might cascade further into seismic restorations.

3. Besides these structural implications, oblique rifting appears to be a major factor in governing the geodynamic evolution of extensional systems. This has been shown via several pieces of evidence. (i) Oblique rifting has been inferred to enhance strain localization by enabling the formation of pull-apart basins and largeoffset strike-slip faults, for instance during the Gulf of California opening (van Wijk et al., 2017; Umhoefer et al., 2018). (ii) Analytical and numerical modelling suggests that the force required to maintain a given rift velocity is anticorrelated with the rift's obliquity. The reason for this behaviour is that plastic yielding takes place at smaller tectonic force when the extension is oblique to the rift trend (Brune et al., 2012). (iii) At the same extension velocity, oblique rifts deform with a certain rift-parallel shear rate, which is balanced by a lower rift-perpendicular extension velocity. This means that oblique segments of a particular rift accommodate lithospheric and crustal thinning at a lower rate than orthogonal segments of the same rift, a difference that effects the thermal configuration and therefore the structural and magmatic evolution of each segment (Montési and Behn, 2007).

4. Oblique rifting holds geodynamic implications on the global scale because of its relation to toroidal plate motion, i.e. vertical axis rotation components of plate movements and associated strike-slip deformation. Toroidal motion is enigmatic from the perspective of plate-driving forces, because its purely horizontal motion cannot be directly caused by buoyancy forces in Earth's interior (Lithgow-Bertelloni et al., 1993; Bercovici, 2003). Oblique rifts feature strike-slip velocity components and therefore contribute to toroidal mo- tion, while orthogonal rifts are an expression of purely buoyancy-driven (poloidal) flow.

The impact of rift obliquity on the structural architecture of continental extensional systems varies between natural cases. This is mainly due to rift variability in general, which arises from tectonic inheritance (Manatschal et al., 2015; Morley, 2016; Hodge et al., 2018; Phillips et al., 2018), or from alongstrike changes in rheology, crustal configuration, temperature, and rift velocity (e.g. Sippel et al., 2017; Molnar et al., 2017; Brune et al., 2017a; Mondy et al., 2017).

Oblique rifting in presently active rifts can be easily deduced by combining the local rift trend and GNSS-based surface velocities (Díaz-Azpiroz et al., 2016). Prominent examples are the Main Ethiopian rift (Corti, 2008), the Levant rift system including the Dead Sea rift (Mart et al., 2005), the Gulf of California rift (Atwater and Stock, 1998; Fletcher et al., 2007), the Upper Rhine graben (Bertrand et al., 2005), and the Cenozoic West Antarctic rift (Rossetti et al., 2003; Vignaroli et al., 2015; Granot and Dyment, 2018). Structure and kinematics of past rift systems have been studied by surveying obliquely rifted margins (Fournier et al., 2004; Lizarralde et al., 2007; Klimke and Franke, 2016; Phethean et al., 2016) and transform continental margins (Basile, 2015; Mericer de Lépinay et al., 2016; Nemčok et al., 2016). However, quantifying rift obliquity of a specific rift system through time is more difficult since the syn-rift velocity evolution needs to be reconstructed from available geophysical and geological data sets. Therefore, a global statistical analysis of rift obliquity through geological time has been missing so far.

Here we strive to fill this gap by deducing the first-order obliquity history of Earth's major rifts from the onset of Pangea fragmentation to the present day. We first describe the applied methods and data sets, then we focus on major individual rift systems that lead to the formation of the Atlantic and Indian Ocean basins before we assess rift obliquity evolution and average obliquity on a global scale.

\section{Methods and data}

\subsection{Rift kinematics}

We quantify extension velocity using the global kinematic plate reconstruction of Müller et al. (2016). This plate model integrates the latest syn-rift reconstructions for the South Atlantic (Heine et al., 2013), North Atlantic (Hosseinpour et al., 2013; Barnett-Moore et al., 2016), Australia-Antarctica separation and India-Antarctica breakup (Williams et al., 2011; Whittaker et al., 2013; Gibbons et al., 2015), and Gulf of California opening (McQuarrie and Wernicke, 2005), among others (Fig. 1).

Restoration of the relative position of continents prior to rifting in the aforementioned regional studies is largely based on deriving the amount of syn-rift extension from present- 

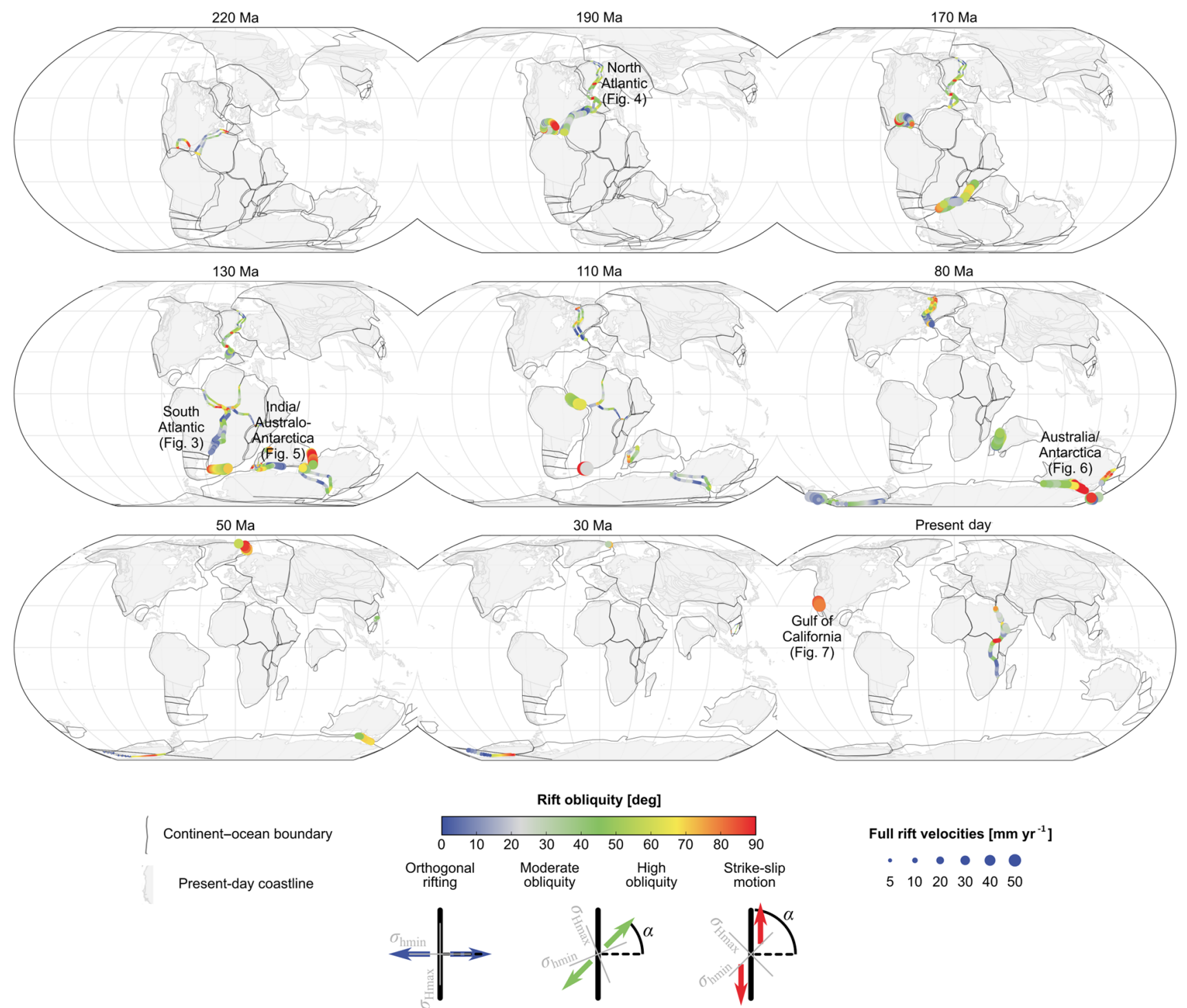

Figure 1. Global overview of rift obliquity and velocity. Rift obliquity is measured as angle $\alpha$ spanned by the relative plate velocity vector and the rift trend normal. Rift kinematics are deduced at sample points along the present-day continental boundaries with a spacing of $50 \mathrm{~km}$. Rift velocity magnitude is represented by circle size (see scale in the lower right corner), rift obliquity by circle colour (see colour bar in the middle). The impact of rift obliquity on the rotation of largest and smallest horizontal stress components $\left(\sigma_{\mathrm{Hmax}}\right.$ and $\sigma_{\mathrm{hmin}}$, respectively) is depicted at the bottom of the figure and is based on relations discussed in Brune (2014). Rotations from Müller et al. (2016). Continent-ocean boundaries from Brune et al. (2016).

day crustal thickness (e.g. Williams et al., 2011; Kneller et al., 2012). The kinematic evolution before breakup, i.e. prior to the occurrence of oceanic fracture zones and oceanic magnetic anomalies, has to be inferred via careful joint interpretation of several geological indicators. Rift initiation for instance can be constrained through the ages of synrift sediments and rift-related volcanism, which give a minimum age for the beginning of rifting (e.g. Chaboureau et al., 2013; Quirk et al., 2013). Later syn-rift kinematics can be inferred from seismic tectono-stratigraphy and dating of rocks that have been drilled or dredged within the continent-ocean transition, while additional information can be derived from kinematic indicators at neighbouring plate boundaries (e.g. Heine et al., 2013; Whittaker et al., 2013).

\subsection{Rift trend}

We define the rift trend as the general direction of a rift segment. Considering a typical rift width of $\sim 100 \mathrm{~km}$, the most suitable wavelength to analyse rift trend variations is several hundred kilometres. There are several possible proxies for 
the rift trend of past continental rift systems: (1) the boundary between continental and oceanic crust, often referred to as continent-ocean boundary (COB); (2) the general trend of the present-day coast line or other bathymetric contours; and (3) rift-related topographic highs (Osmundsen and Redfield, 2011). Note that these proxies do not necessarily yield the same rift orientation and that all of them feature certain disadvantages. Mapping the COB for instance requires seismic refraction data and interpolation between individual profiles, and considering COBs as sharp boundaries does not reflect the crustal complexity in these areas, which mirrors the convoluted interplay of tectonic, magmatic, and sedimentary processes. Coastlines and marginal bathymetry are affected by eustatic sea-level variations and surface processes, as well as tectonic and dynamic topography, while rift-related topographic highs do not exist everywhere and if they do, they are submitted to erosion and post-rift local vertical motions (Jeanniot and Buiter, 2018). Therefore, we employ a workflow where we associate rift trend variations with the $\mathrm{COB}$ orientation (Fig. 2a). We use COBs with deliberately simplified geometries designed to capture the regional geometry of boundaries between continental and oceanic crusts, without a detailed assimilation of local data reflecting fine-scale deviations from these regional trends (see description in Brune et al., 2016). This makes our analysis particularly representative for intermediate and final rift stages since the COB trend is indicative of the rift orientation during and after necking of the mantle lithosphere (Le Pourhiet et al., 2017; Ammann et al., 2017), and allows us to more accurately capture the time dependence of kinematics within rifts that experienced protracted, diachronous breakup. Due to the previously mentioned limitation in defining COBs as single, distinct boundaries, we define two $\mathrm{COB}$ endmember sets that reflect the earliest and latest possible breakup based on available seismic refraction data (Brune et al., 2016). Figure 2a depicts both the early and the late breakup COB data sets exemplified for the North Atlantic illustrating that the overall direction of the rift trend is not affected by the precise location of the COB.

The employed reconstruction is using rigid plate polygons and does not directly capture plate boundary deformation. Thus, in a pre-rift reconstruction, present-day COBs from conjugate passive margins will show significant overlap (Fig. 1), where the amount of overlap is a proxy for the subsequent extension before breakup. As the plates move apart, the overlap decreases, and the moment within the reconstructions where there is no longer overlap in each segment defines the transition from rifting to seafloor spreading. Within this methodology, the two central implications of how we interpret COB geometries for our purposes is that they control the time of breakup along the margins, and that they define the orientation of each rift segment.

\subsection{Rift obliquity}

Using the $\mathrm{COB}$ orientation as a proxy for the rift trend, and accounting for the local direction of relative plate motions, we calculate rift obliquity for all points within an active rift at any time during post-Pangea extension. This workflow is illustrated in Fig. 2b, where we first keep Antarctica fixed in order to evaluate the rift obliquity at an Australian COB location and secondly we fix Australia and estimate rift obliquity for a point at the Antarctic COB. Note that the conjugate values for local rift obliquity are very similar but not the same. We therefore average obliquity values from conjugate margins during our statistical analysis. This analysis is repeated in 1 million-year intervals until the conjugate COBs do not overlap anymore and the tectonic formation of the rifted margin ends.

We apply our workflow in an automated way using the python library pyGPlates that provides script-based access to GPlates functionality. GPlates is a free plate reconstruction software (http://www.gplates.org/, 23 October 2018) that allows for reconstructing and analysing plate motions through geological time (Müller et al., 2018). In the following, we use a spacing of $50 \mathrm{~km}$ between individual sample points where we extract relative plate velocity and obliquity. That spacing is dense enough to capture the relevant changes in rift trend. We also tested smaller point distances, which did not affect our conclusions.

The limitations of this analysis workflow coincide with the limits of plate tectonic reconstructions in general. Many rifts and especially failed rifts are not included in plate tectonic reconstructions yet, which somewhat biases our study towards rifted margins. Future improvements in plate tectonic reconstructions and in defining COBs will enhance our results; however, by testing several endmember scenarios in Sect. 4 we can already anticipate that our main conclusions will still hold even though the detailed values might change.

In this study we follow the convention that defines the angle of obliquity as the angle between extension direction and local rift trend normal. This means that $0^{\circ}$ represents orthogonal rifting while $90^{\circ}$ stands for strike-slip motion. Note that this definition follows many previous studies (e.g. Fournier and Petit, 2007; Philippon et al., 2015; Brune, 2016; Zwaan and Schreurs, 2017; Ammann et al., 2017), but is opposite to the convention used in almost as many articles (e.g. Withjack and Jamison, 1986; Tron and Brun, 1991; Teyssier et al., 1995; Clifton and Schlische, 2001; Deng et al., 2018).

There is clearly a gradual transition from orthogonal rifting to oblique extension, especially since individual fault evolution is subject to natural variability. In this study, however, where we investigate the frequency of oblique rifting, it appears to be useful to draw a line between orthogonal and oblique rifting. In simplified model settings, previous studies suggested that qualitative differences in the rifting style emerge when rift obliquity exceeds 15 to $20^{\circ}$ (Clifton et al., 2000; Agostini et al., 2009; Brune, 2014; Zwaan et al., 2016). 
(a)

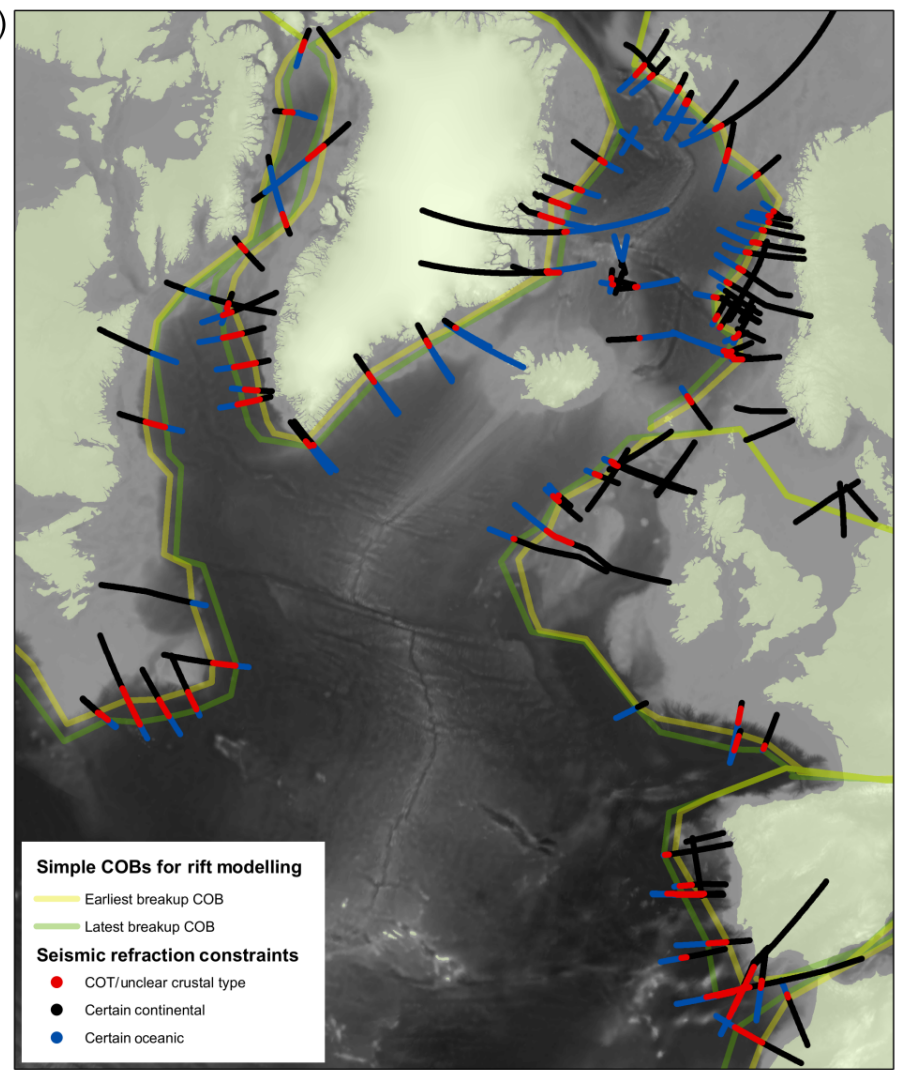

(b)

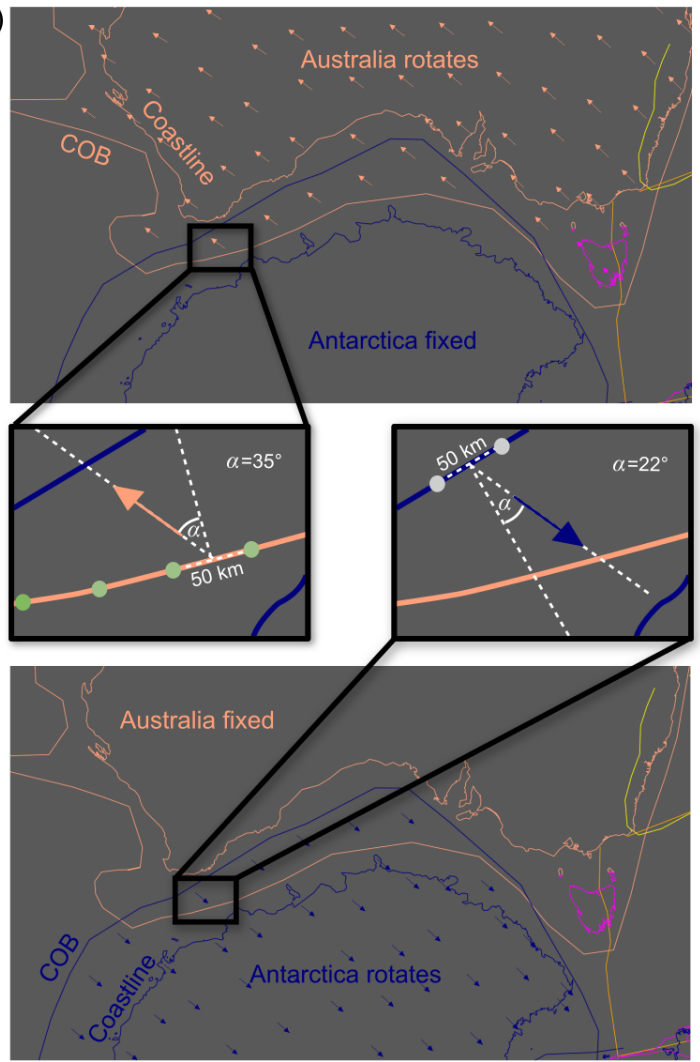

Figure 2. Methods illustration. (a) Endmember sets of continent-ocean boundaries (COBs) are based on seismic refraction data, here exemplified for the North Atlantic. The latest breakup COB constitutes our reference model while the earliest breakup COB is used for robustness tests. (b) Kinematic analysis approach exemplified for Australia-Antarctica rifting.

Keeping in mind that the specific value is somewhat arbitrary, we will use $20^{\circ}$ as the critical obliquity separating orthogonal from oblique rifts.

\section{Regional analysis of individual rift systems}

In this section, our plate tectonic analysis is employed focussing on individual post-Pangea rift systems (Fig. 1). In doing so, we relate the structural history of each rift with its obliquity and velocity evolution.

\subsection{South Atlantic rift}

The orientation of the different South Atlantic rift segments has been affected by reactivation of mobile belts, which formed during the pan-African orogeny in the Neoproterozoic and early Paleozoic (Kröner and Stern, 2005). This reactivation of inherited weaknesses is an ubiquitous process of the Wilson cycle that has also been evoked to explain the formation of the present-day East African rift system (Daly et al., 1989; Hetzel and Strecker, 1994). It has been suggested that $65 \%$ of the South Atlantic rift developed with near-parallel orientation to the pan-African fabric (de Wit et al., 2008) evidencing the strong control of tectonic inheritance on the South Atlantic rift obliquity.

We find that low obliquity predominates in the central and southern segment of the South Atlantic rift (Fig. 3). High rift obliquities are encountered in the Equatorial Atlantic and in the southernmost shear zone that ultimately develops into the Falkland-Agulhas fracture zone. Our analysis shows that the South Atlantic initially features a wide range of rift obliquities (Fig. 3b) and trends to higher obliquity after 120 million years ago (Ma) when only the northern and southernmost segments are active. The frequency diagram of rift obliquity displays a bimodal distribution with the $0-25^{\circ}$ range representing the southern South Atlantic while the 45-65 range is dominated by Equatorial South Atlantic rift geometry (Fig. 3c). The overall mean obliquity at $38^{\circ}$ lies between these two peaks while $68 \%$ of the rift formed at moderate to high rift obliquity larger than $20^{\circ}$.

The rotational rifting of the South Atlantic with an initial Euler pole close to west Africa leads to higher rift velocities in the south than in the north. The mean rift velocity of the entire rift system displays an initial, slow phase lasting more than 20 million years, followed by rift acceleration during a few million years and finally a fast phase of rift- 
(a)

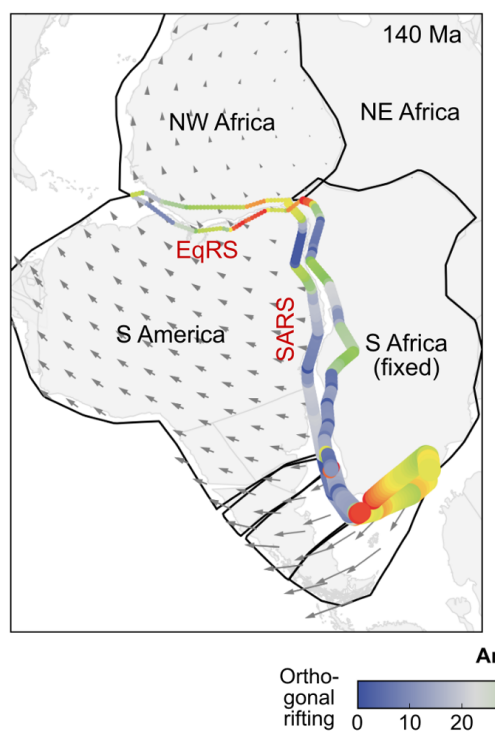

South Atlantic rift

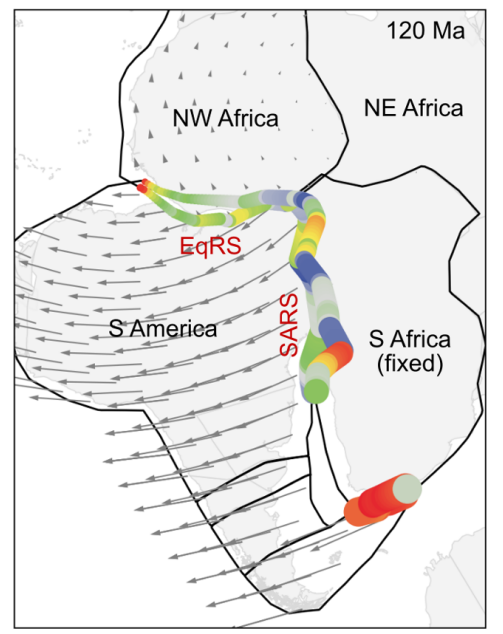

Angle of obliquity [deg]

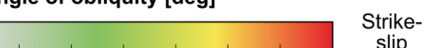

(b) Frequency of rift obliquity

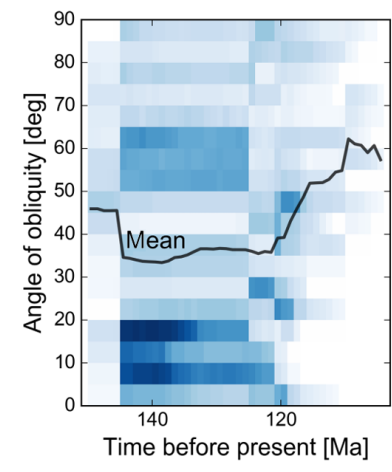

(c) Cumulative frequency [\%]

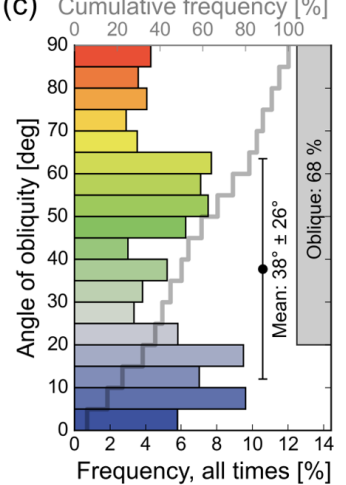

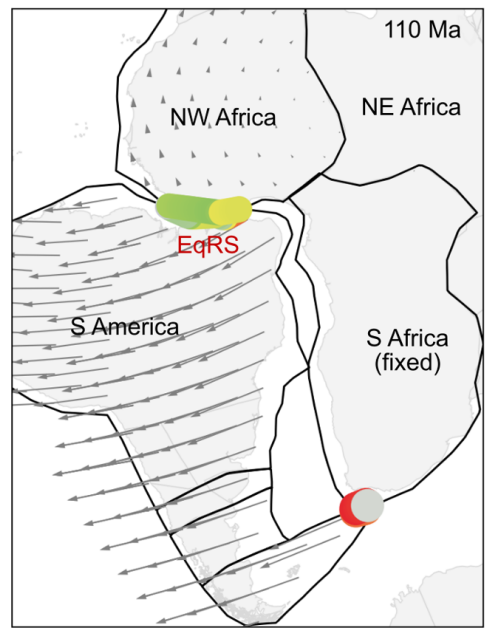

Full rift velocities [ $\mathrm{mm} \mathrm{yr}^{-1}$ ]

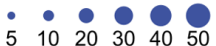

(d) Frequency of rift velocity

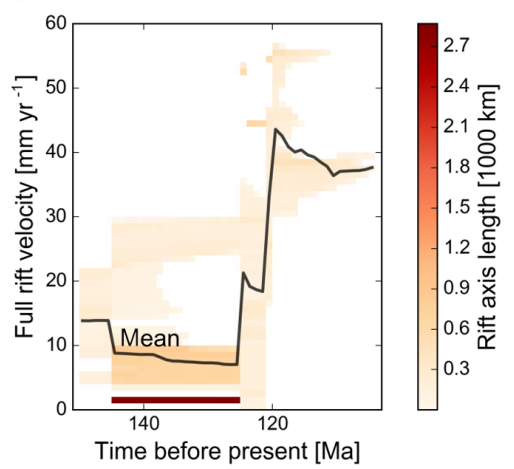

Figure 3. South Atlantic rift. (a) Tectonic reconstruction of continental polygons. The magnitude of the local relative plate velocity along the rift system is represented by circle size, rift obliquity by circle colour. Relative velocities of continents with respect to a fixed south Africa are depicted as grey vectors. All velocities are based on the global reconstruction of Müller et al. (2016) and analysed using pyGPlates. Low rift obliquity prevails in the central and southern segment of the South Atlantic rift, whereas high obliquities and strike-slip motion dominates the northern and southernmost segments. EqRS: Equatorial Atlantic Rift System, SARS: South Atlantic Rift System. (b) Frequency of rift obliquity in terms of rift axis length. The colour displays the integrated length of all rift segments that deform at the same rift obliquity. (c) Cumulative distribution of rift obliquity throughout the entire rift event. Bar colour represents obliquity. (d) Time-dependent frequency of rift velocity in terms of rift axis length. Colour shows integrated length of all segments deforming at the same velocity. Note that rift velocity and obliquity increase jointly starting at $120 \mathrm{Ma}$.

ing prior to the transition to sea-floor spreading (Heine et al., 2013; Brune et al., 2016). This two-phase evolution can also be seen in alternative reconstructions (Nürnberg and Müller, 1991; Torsvik et al., 2009; Moulin et al., 2010; Granot and Dyment, 2015) although it is partitioned between individual South American blocks for some studies (Brune et al., 2016). Interestingly, the evolution of rift obliquity and velocity appears to be correlated, which we will discuss in Sect. 5.

\subsection{North Atlantic rift}

The formation of the North Atlantic involved a protracted rift history involving several major plates (Eurasia, Greenland, Iberia, North America). Initial inherited weaknesses from the Caledonian orogeny have been reactivated in episodic continental extension that is recorded in Carboniferous to Permian basins (Doré, 1991; Lundin and Doré, 1997). The Mesozoic is marked by extensive crustal thinning that lead to formation and abandonment of major rift arms like the Rockall Trough, the Porcupine, Orphan, Møre, and Faroe-Shetland basins (Skogseid et al., 2000; Faleide et al., 2008; Peron- 
Pinvidic et al., 2013). However, Mesozoic rifting also induced continental breakup in the Iberia-Newfoundland segment, the Bay of Biscay, and the North Atlantic rift south of Greenland (Féraud et al., 1996; Tugend et al., 2014; Nirrengarten et al., 2018). Opening of the Labrador Sea and rifting between Greenland and Europe competed for many tens of millions of years (Dickie et al., 2011; Hosseinpour et al., 2013; Barnett-Moore et al., 2016) before the present-day northeast Atlantic mid-ocean ridge formed in Eocene times (Gernigon et al., 2015; Gaina et al., 2017) possibly due to the arrival of the Iceland hotspot (Coffin and Eldholm, 1992; Storey et al., 2007). Final separation between Greenland and Europe took place along the sheared margin of the Fram Strait in Miocene times 17-15 Ma (Jakobsson et al., 2007; Knies and Gaina, 2008).

Multiple plate motion changes reflect the complex tectonic history of the North Atlantic during the last 200 million years. These changes translate to time-dependent rift obliquity in each of the major rift branches (Fig. 4). Between 200 and $120 \mathrm{Ma}$, the rift branches east and south of Greenland deform at 35 to $60^{\circ}$ rift obliquity which leads to a pronounced peak within this obliquity range in Fig. $4 \mathrm{~b}$ and $\mathrm{c}$. This changes in the Early Cretaceous with the more northward movement of Greenland and generates almost orthogonal rifting between Greenland and Europe until breakup. Due to the northward propagation of sea-floor spreading, the Iberia-Newfoundland rift is excluded from the later plate motion changes and hence formed during low extension obliquity. The latest stage of continental rifting is marked by more than 30 million years of high-obliquity shear between northern Greenland and northwest Europe.

The absolute frequency of rift obliquity is marked by two peaks at 0 and $45^{\circ}$ (Fig. 4c). While this bears some similarity with the South Atlantic (Fig. 3c), the underlying reason for these two distinct peaks is not linked to the different orientation of two rift branches (like in the South Atlantic), but is a result of Greenland's plate motion change at around $120 \mathrm{Ma}$ (Fig. 4a, b). Except for Iberia-Newfoundland and the Labrador Sea branches, which evolved at low obliquity, most rift branches experienced moderate or high rift obliquity during the entire rift history. More than $70 \%$ of the rifts involved an obliquity of more than $20^{\circ}$ and the overall mean obliquity of the North Atlantic rift amounts to $34^{\circ}$ (Fig. 4c).

\subsection{Rifting between India and Australo-Antarctica}

Mesozoic rifting within eastern Gondwana led to continental fragmentation beginning with the separation of India (together with Sri Lanka and Madagascar) from Australia and Antarctica in the Middle-Jurassic to Early Cretaceous (Powell et al., 1988; Gibbons et al., 2013). The timing and kinematics of breakup and spreading between Australia and India is well constrained (Williams et al., 2013; Whittaker et al., 2016) and although the precise geometry of greater India is obscured by subsequent deformation during India-Eurasia collision, the divergence between India and Australia is thought to have involved a significant component of oblique motion along greater India's northern margin recorded by the Wallaby-Zenith Fracture Zone (Ali and Aitchison, 2014). Initial breakup between India and Antarctica is recorded in the Enderby Basin becoming progressively younger to the west (Gibbons et al., 2013; Davis et al., 2016) and involved significant ridge jumps that isolated the Elan Bank microcontinent (Borissova et al., 2003).

Rotational rifting between east India and AustraloAntarctica with an Euler pole close to the southwestern tip of India induces almost orthogonal rifting between India and Antarctica, and predominantly oblique rifting between India and west Australia (Fig. 5). After $135 \mathrm{Ma}$, continued high obliquity shear along the northern Indian margin and Australia finally culminates in the formation of the WallabyZenith Fracture Zone, the northern boundary of the Perth Abyssal Plain. At the same time, breakup propagates from east to west along the east Indian margin, so that the mean rift obliquity is more and more dominated by high-angle shearing.

The rift obliquity distribution in Fig. $5 \mathrm{c}$ reflects the existence of two major rift trends - the low obliquity IndiaAntarctica branch of 0 to $25^{\circ}$ and the highly oblique IndiaAustralia branch with more than $45^{\circ}$. The mean obliquity of the entire rift system amounts to $32^{\circ}$ while more than $60 \%$ of the rift evolved at obliquity angles higher than $20^{\circ}$. Prior and during large parts of the breakup, the velocity and obliquity of the rift system are positively correlated.

\subsection{Australia and Antarctica}

The first phases of rifting between Australia and Antarctica began in the Late Jurassic (Powell et al., 1988; Ball et al., 2013) but continental breakup did not begin until the Late Cretaceous and progressed diachronously from west to east. Within this rift system, the signatures of oblique extension have been previously recognized along Australia's southern margin (Willcox and Stagg, 1990; Norvick and Smith, 2001). Lithospheric breakup was complex and protracted (Gillard et al., 2015, 2016), leaving unresolved questions surrounding the nature of the crust in the continent-ocean transition and the oldest interpreted seafloor spreading magnetic lineations. Reconstructions of the rift kinematics must therefore incorporate other geological constraints from along the Australia-Antarctica plate boundary system (Whittaker et al., 2013; Williams et al., 2018). This reconstruction, in common with earlier studies (Powell et al., 1988; Royer and Sandwell, 1989), comprises an oblique component of divergence during the Late Cretaceous prior to a change in plate motion direction in the early Cenozoic.

The first-order history of rift obliquity can be understood by considering two distinct conditions. (i) Due to the concave shape of the southern Australian margin and their Antarctic conjugates, there are two major rift trends along the 
(a)

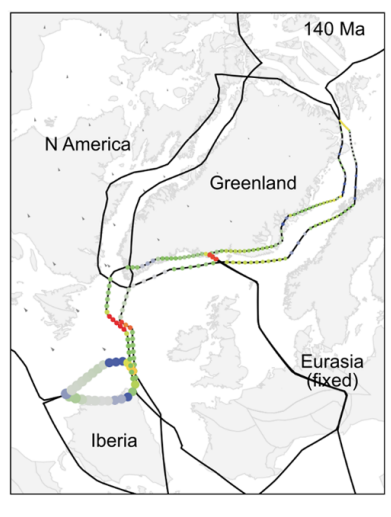

North Atlantic rift

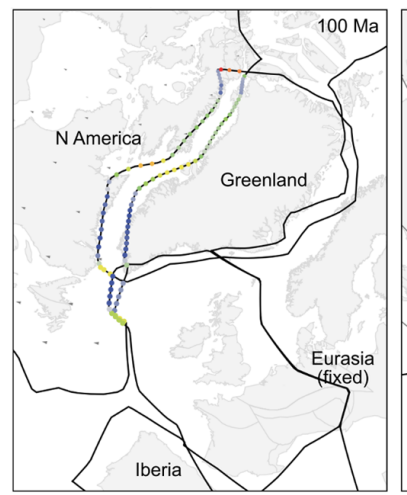

Angle of obliquity [deg]

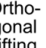

gonal
rifting

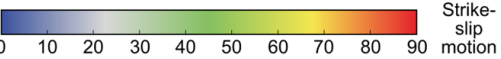

(b) Frequency of rift obliquity

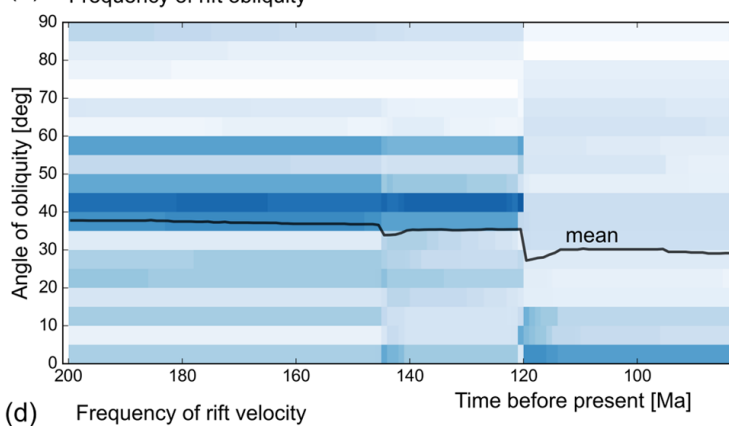

(d)

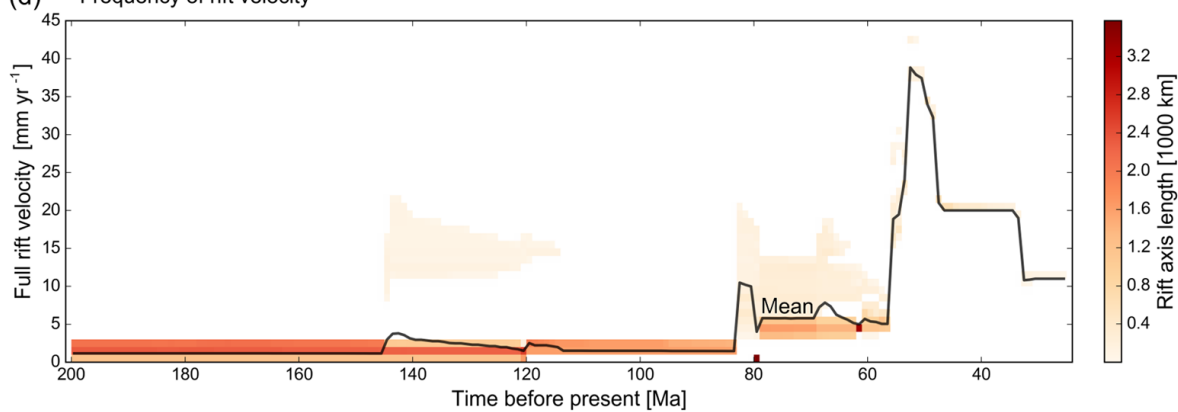

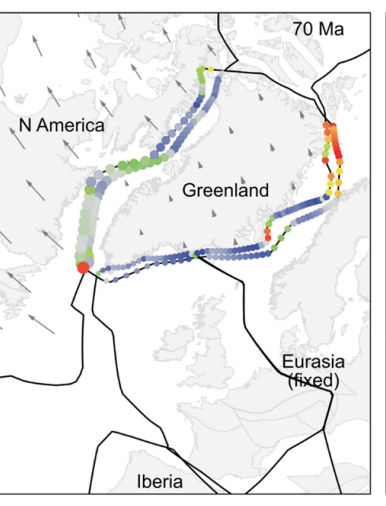

Full rift velocities $\left[\mathrm{mm} \mathrm{yr} \mathrm{r}^{-1}\right]$

51020304050

(c) Cumulative frequency [\%]

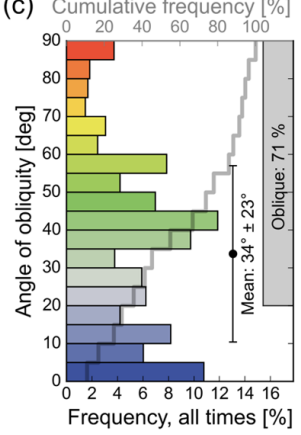

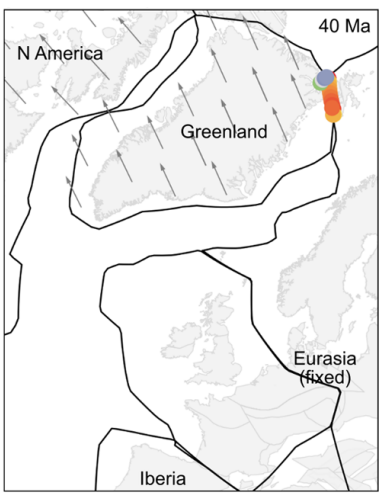

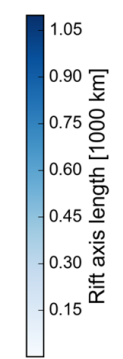

Figure 4. North Atlantic rift. Several changes in plate motion mirror the complex tectonic history of the North Atlantic during the last 200 million years. A distinct increase in syn-rift obliquity occurs at 50 Ma prior to final breakup between northern Greenland and northwest Europe. For explanation of symbols and diagrams see caption of Fig. 3.

Australia-Antarctica rift (Fig. 6). (ii) According to the plate tectonic reconstruction (Williams et al., 2011), there has been a significant change in relative plate motion at around $100 \mathrm{Ma}$ from a northward to a northwestward-directed plate velocity. The two existing rift trends explain the dichotomy in rift obliquity of $10-25$ and $35-45^{\circ}$ from the onset of rifting until $100 \mathrm{Ma}$ (Fig. 6b). The plate motion change at $100 \mathrm{Ma}$, however, shifts the rift obliquity in both branches to higher angles of $20-45$ and $80-90^{\circ}$, respectively.

The velocity history displays a prominent increase at $100 \mathrm{Ma}$ that corresponds to the increased rift obliquity via a plate motion change. An increase in the rate of plate di- vergence in the Late Cretaceous is corroborated by structural restoration studies based on seismic profiles (Espurt et al., 2012) and the rate of divergence is similar to that interpreted from initial seafloor spreading anomalies (Tikku and Cande, 1999; Whittaker et al., 2013). Interestingly, after more than 20 million years of fast divergence, the relative plate velocity inferred from magnetic anomalies decreases again. If correct, this decrease cannot be related to Australia-Antarctica plate boundary dynamics, since at this time the rift system only consists of the last remaining continental bridge between Tasmania and Antarctica while the majority of the plate boundary already transitioned to sea-floor spreading. 
(a) India / Australo-Antarctica rift

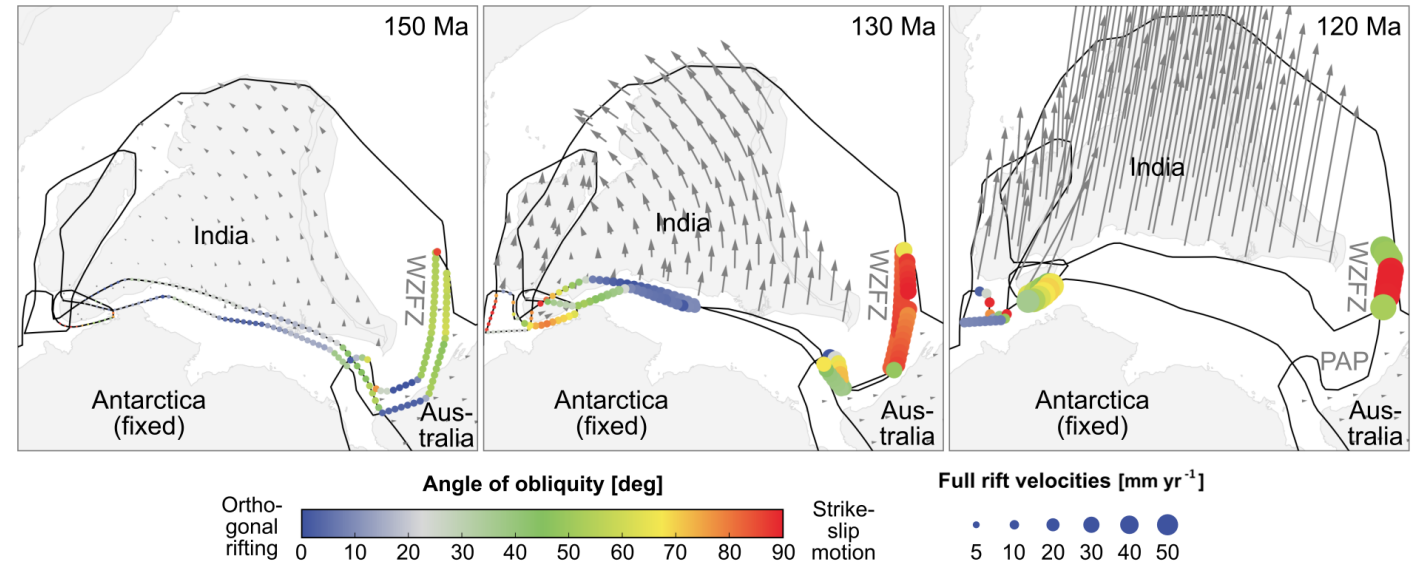

(b) Frequency of rift obliquity

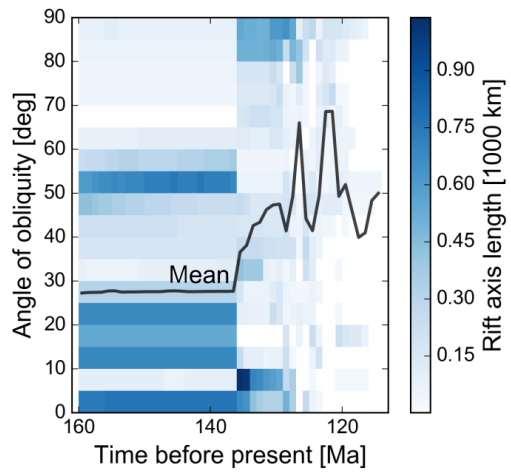

(c) Cumulative frequency [\%]

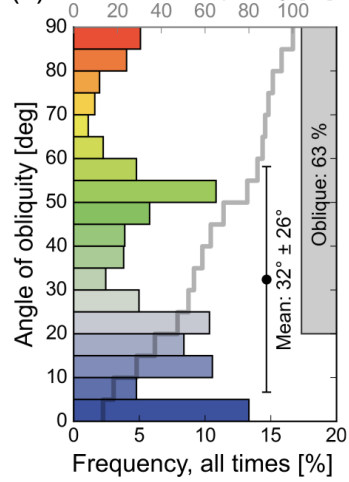

(d) Frequency of rift velocity

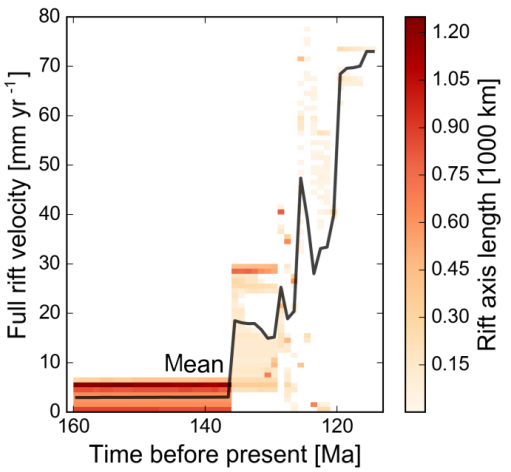

Figure 5. India / Australo-Antarctica rift. Rift obliquity is dominated by two major rift trends: the low-obliquity India-Antarctica branch and the highly oblique India-Australia branch. For simplicity, we neglect low-velocity relative motion between Antarctica and Australia, which will be discussed in Fig. 6. WZFZ: Wallaby-Zenith Fracture Zone, PAP: Perth Abyssal Plain. For explanation of symbols and diagrams see caption of Fig. 3.

A further noteworthy aspect of Australia-Antarctic divergence is the failure of rifting between Tasmania and the southeast Australian mainland. Extension in the Bass and Gippsland basins occurred predominantly in the Early Cretaceous (e.g. Power et al., 2001). In the Late Cretaceous, rifting between Australia and Antarctica localized between western Tasmania and Cape Adare, where breakup eventually occurred. The higher obliquity of the successful plate boundary compared to the failed rift arm in Bass Strait may explain why this rift was favoured, similar to the successful opening of the Equatorial Atlantic in favour of a Saharan ocean during South Atlantic formation (Heine and Brune, 2014).

\subsection{Gulf of California}

The Gulf of California constitutes the youngest rift system in our analysis, which is why its temporal evolution is known in much greater detail than the previous examples. The first phase of the Gulf of California rift is closely linked to the greater Basin and Range extensional zone. Tectono- stratigraphy and dated rift-related magmatic rocks show that the onset of continental extension must have occurred before the mid-Miocene (Ferrari et al., 2013; Duque-Trujillo et al., 2015). This first phase of slow rifting is marked by a wide rift style characteristic of the present-day Basin and Range Province. An increase in both rift velocity and rift obliquity has been suggested as the underlying reason for basin-ward localization and finally the transition to sea-floor spreading in the southern Gulf of California (Bennett and Oskin, 2014; Darin et al., 2016; van Wijk et al., 2017). This change in plate motion at $\sim 12 \mathrm{Ma}$ has been explained by the final cessation of subduction in this region so that most of the relative plate motion between the Pacific and North America had to be taken up by transform motion between Baja California and the North American mainland (Atwater and Stock, 1998; Oskin and Stock, 2003).

The transition from orthogonal to highly oblique rifting is captured by the tectonic reconstruction (McQuarrie and Wernicke, 2005) our plate model is built on (Fig. 7a). According to that reconstruction, the transition occurs during a time 
(a) Australia / Antarctica rift

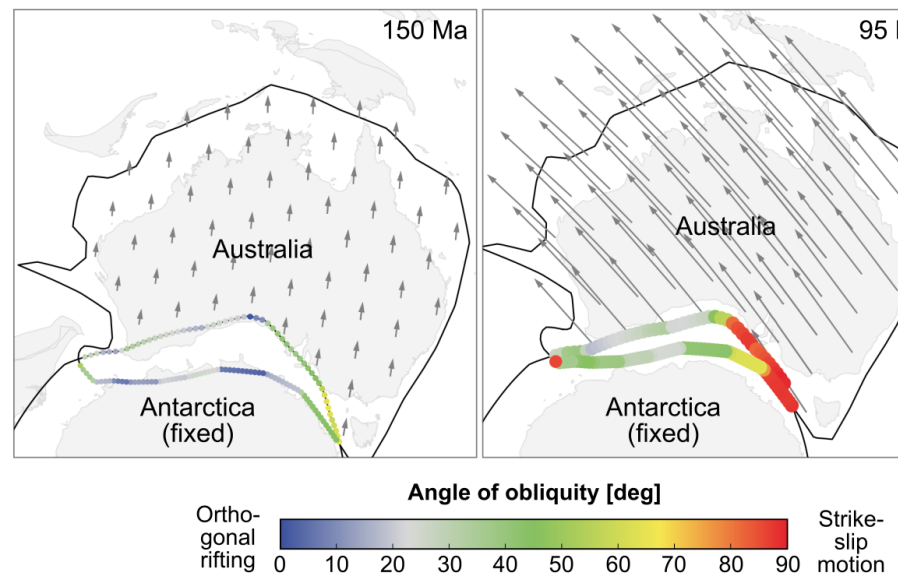

$95 \mathrm{Ma}$

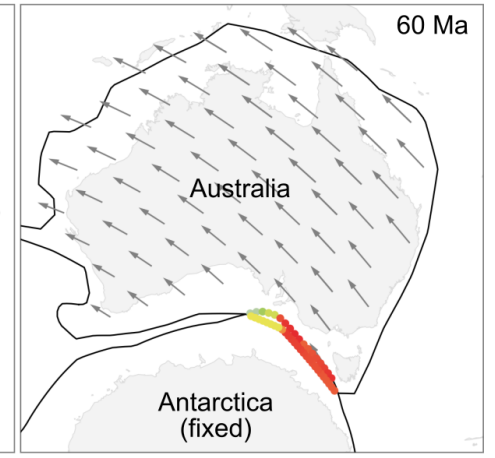

Full rift velocities $\left[\mathrm{mm} \mathrm{yr}^{-1}\right]$

- $\bullet \bullet \bullet \bigcirc$

(b) Frequency of rift obliquity

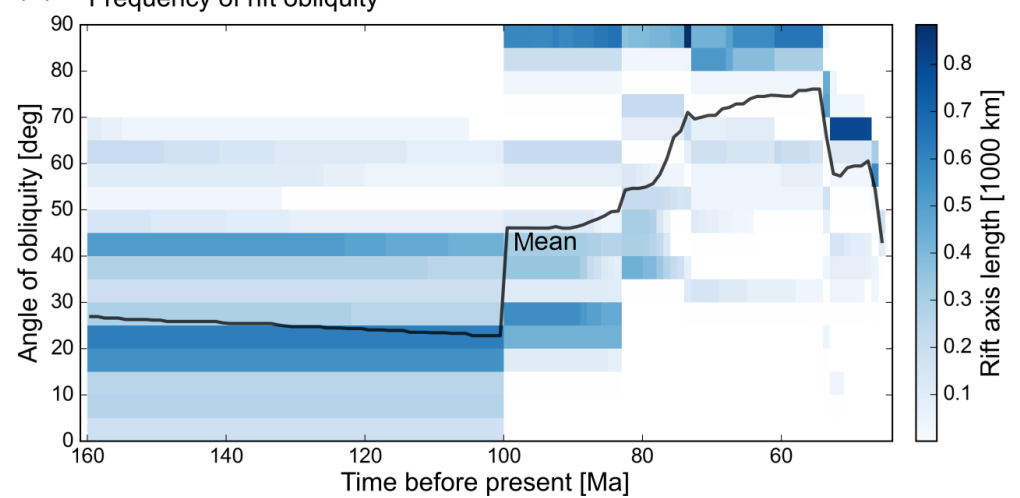

(c) Cumulative frequency [\%]
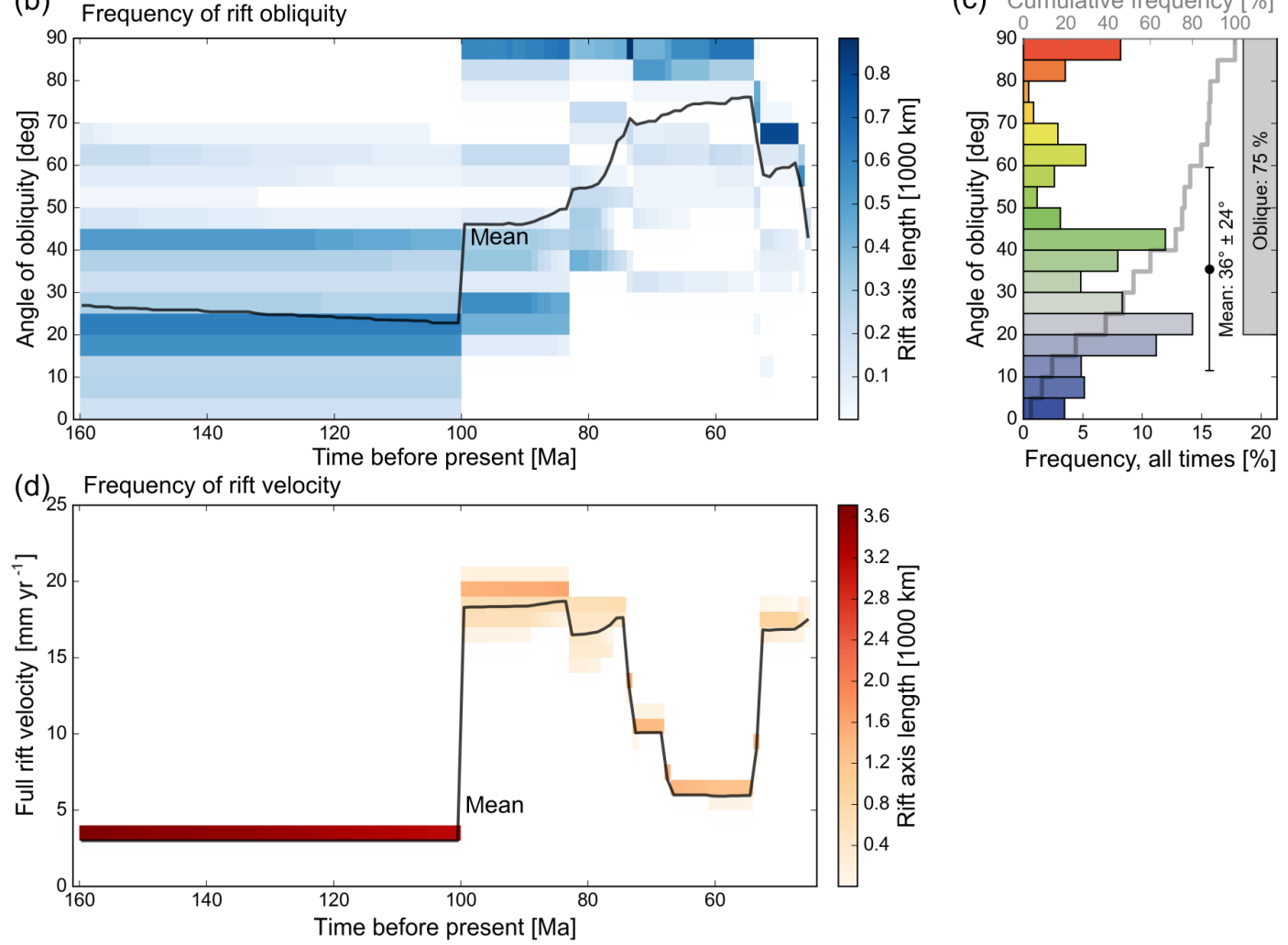

Frequency, all times [\%]

Figure 6. Australia / Antarctica rift. A distinct change in plate motion takes place at 100 Ma generating two discrete phases: (1) slow rifting at moderate obliquity and (2) fast rifting at high obliquity. For explanation of symbols and diagrams see caption of Fig. 3.

frame of less than 10 million years between 20 and $10 \mathrm{Ma}$ (Umhoefer, 2011). That transition is mirrored in our analysis by a gradual increase in rift obliquity from less than $10^{\circ}$ prior to $18 \mathrm{Ma}$ to $20-25^{\circ}$ between 18 and $12 \mathrm{Ma}$ up to $40-90^{\circ}$ from $12 \mathrm{Ma}$ until the present day (Fig. 7b).

A striking feature of the Gulf of California rift is that throughout the existence of this plate boundary the velocity evolved almost proportional to the rift obliquity (Fig. 7b, d) hinting at a causal relationship between these two variables.
Observations from the Gulf of California rift corroborate the idea that localization within the lithosphere is enhanced by obliquity-related formation of pull-apart basins and associated energy-efficient strike-slip faults (Bennett and Oskin, 2014; van Wijk et al., 2017). We discuss the relation of rift obliquity and extension velocity in more detail in the Discussion (Sect. 5). 
(a)

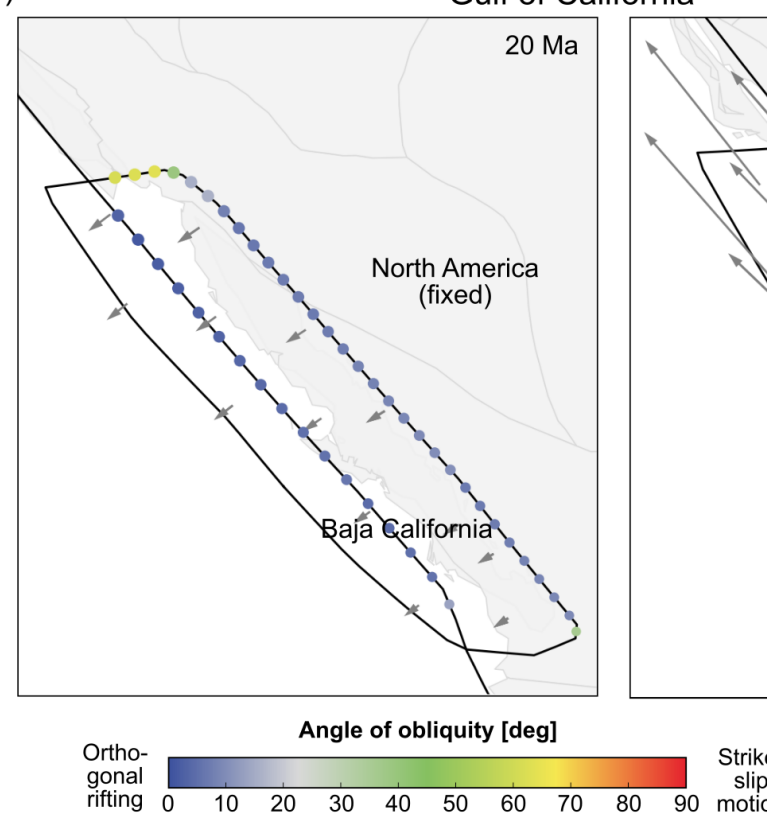

(b) Frequency of rift obliquity

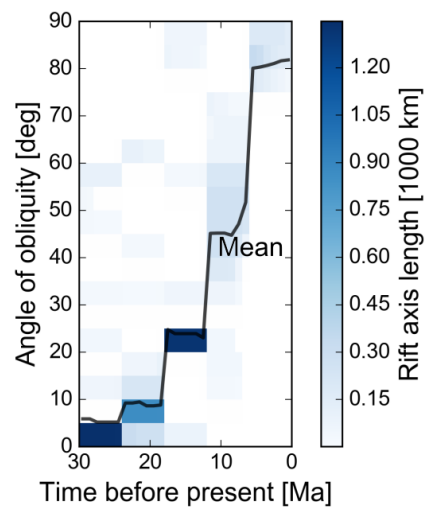

(c) Cumulative frequency [\%]

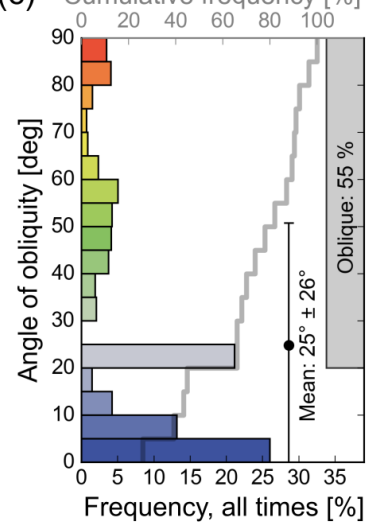

(d) Frequency of rift velocity

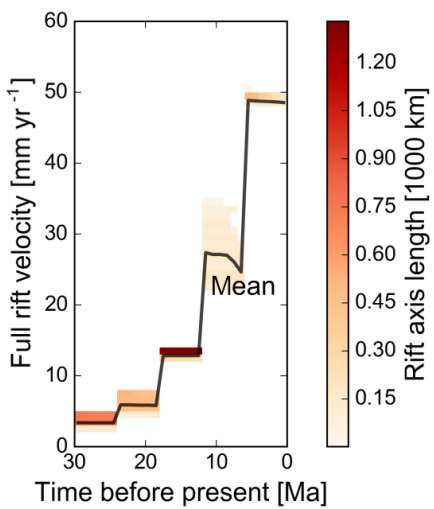

Figure 7. Gulf of California rift. The initial rift phase is characterized by slow, predominantly orthogonal extension and associated with a wide rift. An increase in rift obliquity enhances localization between 20 and $10 \mathrm{Ma}$ inducing continental breakup. The obliquity and velocity of this rift increases almost proportionally. For explanation of symbols and diagrams see caption of Fig. 3.

\section{Global analysis}

In this section we evaluate global rift obliquity since the onset of Pangea fragmentation in terms of temporal and spatial variability. Analysing all rift systems of our global plate tectonic model during the last 230 million years, we test the robustness of our study by additionally considering the impact on passive margin area and by employing an alternative set of continent-ocean boundaries.

The extent of major rift systems varied through time (Fig. 8a), with a pronounced peak between 160 and 110 million years ago when many rifts of the Atlantic and Indian Ocean were simultaneously active. Figure $8 \mathrm{~b}$ illustrates that almost all angles of obliquity are represented at any given time. Interestingly, obliquities in the range between 70 and $85^{\circ}$ seem to be under-represented while almost pure strikeslip systems are an ubiquitous feature. This finding might be explained by the fact that the transition from normal faulting to strike-slip faulting in ideal materials occurs at obliquities around $70^{\circ}$ (Withjack and Jamison, 1986). We therefore speculate that once major continental strike-slip faults form, the plate boundary adjusts to a velocity-parallel configuration entailing the formation of a transform margin (Gerya, 2013; Le Pourhiet et al., 2017; Ammann et al., 2017), which also explains the relatively high peak at $90^{\circ}$ obliquity (Fig. 8 b, c). 
(a)
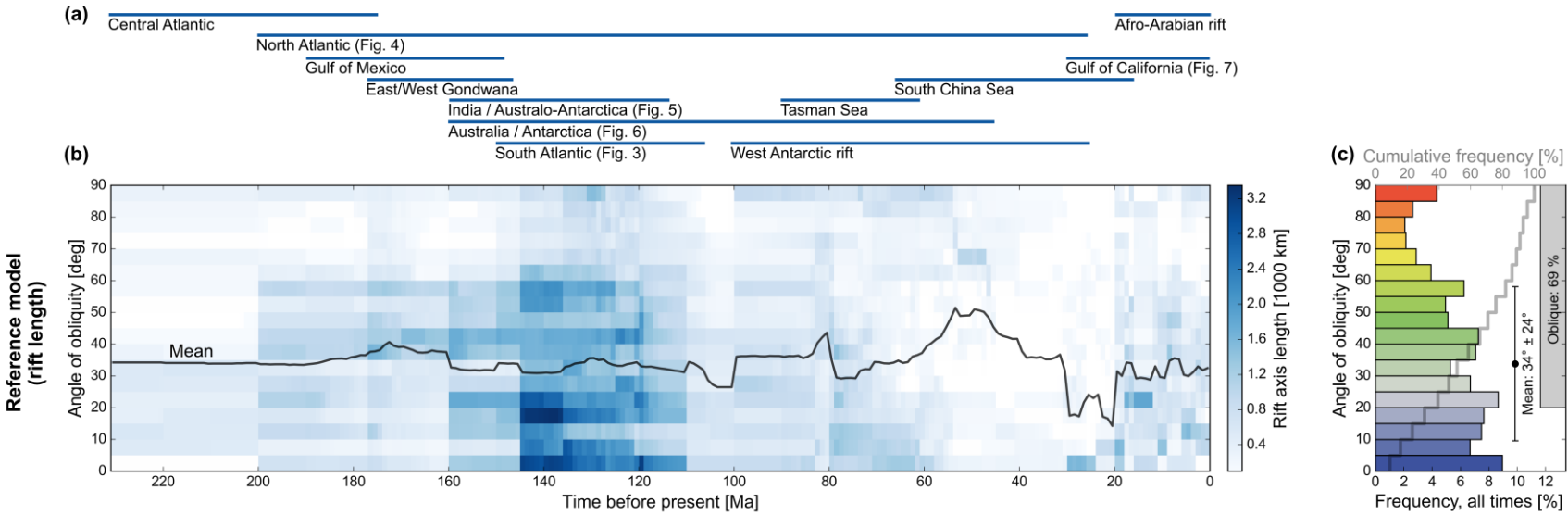

(d)

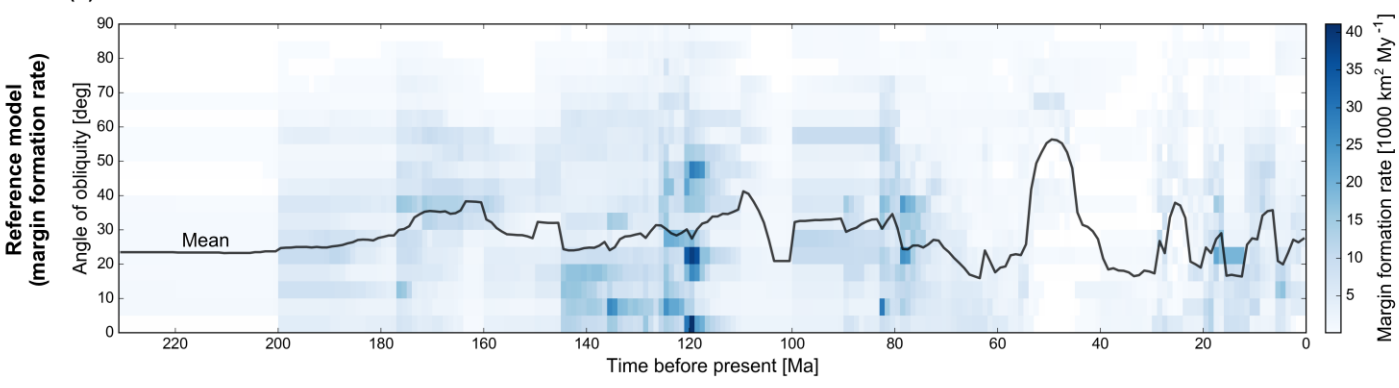

(e) Cumulative frequency $[\%$

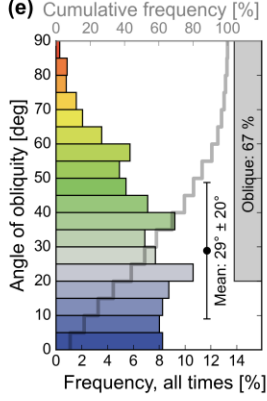

(f)
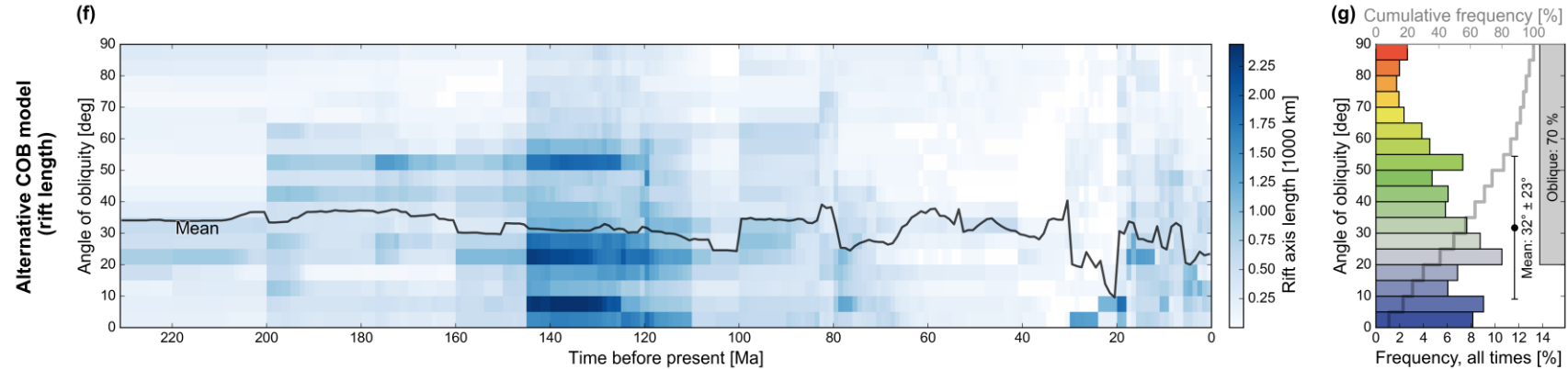

Figure 8. Global analysis of rift obliquity. (a) Variations of major rift system activity. Note that many rifts of the Atlantic and Indian Ocean were simultaneously active between 160 and $110 \mathrm{Ma}$. (b, c) Rift obliquity in terms of rift length for the reference model employing latebreakup COBs (see Sect. 2.2 and Figs. 1 and 2 for more details). (d, e) The reference model analysed in terms of margin formation rate (i.e. rift segment length multiplied with segment-orthogonal velocity component). (f, g) An alternative model employing early-breakup COBs. All three models result in global mean rift obliquities of $\sim 30^{\circ}$ and oblique rifting for more than $\sim 70 \%$ illustrating the robustness of our results.

In our reference model, we compute a mean global obliquity of $34^{\circ}$ with a standard deviation of $24^{\circ}$ since the inception of Pangea breakup. We also find that $69 \%$ of all rifts deform in oblique rift mode, i.e. with obliquities exceeding $20^{\circ}$ (Fig. 8c), illustrating that oblique rifting appears to be the rule on Earth rather than the exception.

So far, we analysed the frequency of obliquity with respect to rift length, where transform margins and rifted margins are given the same relative importance. Now we focus briefly on the surface area that is generated during passive margin formation, which is also a proxy for the size of sedimentary basins. We note that it is the rift-orthogonal velocity component which leads to lithospheric stretching and generates passive margin area, while the rift-parallel component merely induces an along-strike offset. Hence we compute how many square kilometres of passive margin are generated per million year by multiplying the rift length of each small rift segment with its segment-orthogonal velocity component. The resulting distribution reflects the relative importance of rift obliquity weighted by passive margin area, which essentially leads to a shift towards lower obliquity values. Nevertheless, we find an average obliquity of $29^{\circ}$ and a total of $67 \%$ of passive margin area affected by obliquity angles larger than $20^{\circ}$ (Fig. 8d, e).

We test the impact of an alternative set of continentocean boundaries (Fig. 2), which represents the continent- 
ward endmember and hence stands for an earlier breakup time (Sect. 2.2). While the total rift length is reduced with respect to the reference model, we find that the first-order pattern of obliquity evolution is not affected (Fig. 8f, g). Also, the mean rift obliquity of $32^{\circ}$ and the rift length percentage affected by oblique deformation ( $70 \%$ ) is almost identical to the late-breakup endmember.

Finally, we map the time-averaged obliquity at each rift element (Fig. 9). The advantage of this approach is that one can easily identify each point's rift obliquity that dominated the tectonic evolution, however, one has to keep in mind that changes in rift obliquity are not visualized. Figure 9 shows that only a few rifts exhibit a pure rift-orthogonal extension velocity such as the Labrador Sea, the east Indian margin and some locations in the North Atlantic and South Atlantic. Instead, many rifted margins feature moderate rift obliquity between 20 and $40^{\circ}$ like the west Iberia margin, the Red Sea, as well as the central and southern segment of the South Atlantic. To a large extent, however, the dominant rift obliquity exceeds even $40^{\circ}$, for instance in the Gulf of Mexico, the Equatorial South Atlantic, the Gulf of Aden, the east African margins, the West Antarctic rift, the Tasman Sea and also the sheared margins of the Fram Strait, Madagascar, Patagonia, and Western Australia.

\section{Discussion}

Previous studies quantified the present-day plate boundary obliquity in general terms and on long wavelength by considering extensional, compressional, and transform plate boundary types. Woodcock (1986) noted that $59 \%$ of all presentday plate boundaries feature obliquities larger than 22 degrees. A more detailed recent study found even higher obliquity by showing that $65 \%$ of present-day plate boundaries exhibit $>30^{\circ}$ obliquity (Philippon and Corti, 2016). In the latter study, this result was further decomposed by plate boundary type illustrating that $73 \%$ of rifts and mid-ocean ridges extend at more than $30^{\circ}$ obliquity. While these previous studies did not focus on rift obliquity, they nevertheless are consistent with our results by highlighting that oblique plate boundary deformation constitutes the rule and not the exception.

Jeanniot and Buiter (2018) evaluated the margin width of transtensionally formed rifted margins and thereby estimated the rift obliquity of 26 major rift segments worldwide. In general, their approach is very similar to ours: they defined linearized rift segments that follow the trend of continentocean boundaries, additionally accounting for coastlines and topographic highs, and they estimated the direction of relative plate divergence using the GPlates graphical user interface. They find a weak positive correlation between obliquity and width of a rift system; however, at highly oblique margins this relationship breaks down and these margins are not only significantly narrower than orthogonal margins but they also exhibit large-offset transform faults. Our approach differs from Jeanniot and Buiter (2018) in that our linearized rift segments are considerably smaller (of the order of several hundred kilometres), that we employ a script-based approach using the python interface of GPlates and that we include a few more regions, but most importantly that we explicitly focus on the temporal evolution of rift obliquity. Nonetheless, for the time-averaged obliquity (Fig. 9) we find a very good correspondence with their results, which illustrates the robustness of both approaches with respect to the exact definition of the rift trend and the linearized rift segment length.

The dynamics of oblique rifting have been previously investigated using numerical and analogue modelling methods. In these experiments, rift obliquity is imposed through oblique lateral boundary conditions (Schreurs and Colletta, 1998; Brune, 2014; Zwaan et al., 2016), boundaries with a velocity discontinuity (Tron and Brun, 1991; Bonini et al., 1997; Le Calvez and Vendeville, 2002; Le Pourhiet et al., 2012), an oblique arrangement of weak elongate zones (van Wijk, 2005; Corti, 2008; Agostini et al., 2009; Ammann et al., 2017; Brune et al., 2017b; Balázs et al., 2018), or offset weak seeds (Allken et al., 2012; Gerya, 2013; Le Pourhiet et al., 2017). The majority of these studies focus on emergent fault patterns and their evolution, and relate the existence of oblique rifts and rifted margins to tectonic inheritance, segment linkage, rift propagation, and changes in extension direction. Some models, however, were designed to investigate the required driving force during oblique extension (Brune et al., 2012) and the competition between simultaneously active, neighbouring rift systems (Heine and Brune, 2014). These models suggest oblique rifting as a mechanically preferred type of continental extension and we speculate that this could be a reason for the unexpectedly high percentage of oblique rifts and rifted margins in our analysis. The underlying cause for preferentially oblique rifting has been addressed by means of analytical modelling suggesting that plastic yielding takes place at less tectonic force when the relative plate velocity is oblique to the rift trend (Brune et al., 2012). This process exerts additional control on rift strength that is otherwise governed by thermo-rheological properties, strain localization, and inherited weaknesses (Buck, 2015; Burov, 2015; Brune, 2018). As a consequence, during rift competition, oblique rifting should prevail over orthogonal rifting if all other rift parameters are similar. This appears to be the case for the west African and Equatorial Atlantic rift systems, which were active at the same time until localization along the more oblique Equatorial Atlantic rift induced the failure of the West African rift (Heine and Brune, 2014). A similar example is continental rifting between Australia and Antarctica, where early extension formed failed rift basins within the present-day Bass Strait (e.g. Norvick and Smith, 2001) that competed with the more oblique and eventually successful rift between Tasmania and Antarctica.

In many cases, we find a correlation between the obliquity and the velocity of a rift (Figs. 3-7). This result can be under- 


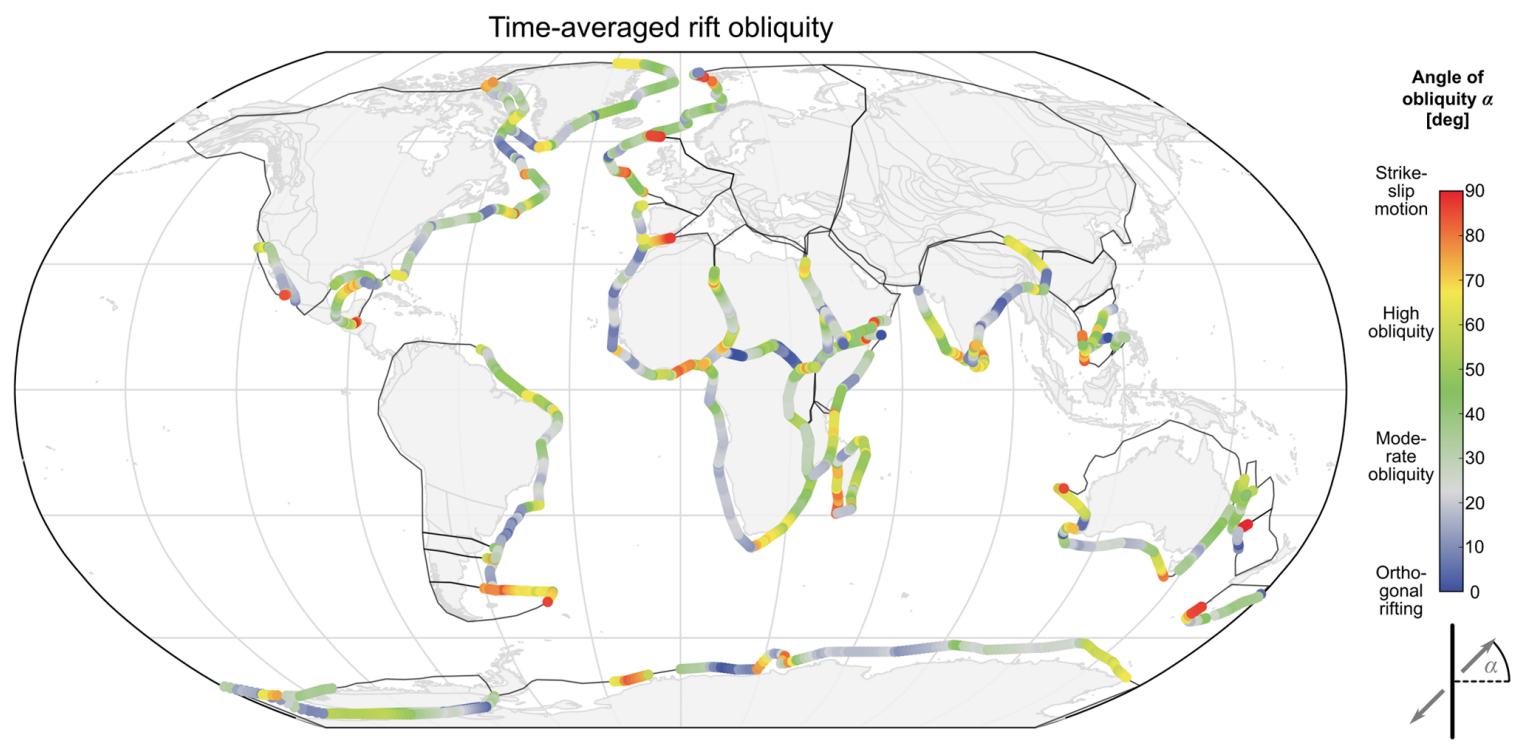

Figure 9. Global map of mean rift obliquity. For each rift point we display the time-averaged rift obliquity illustrating the prevalence of oblique rifting since Pangea fragmentation. Note that temporal changes in rift obliquity cannot be visualized in this plot.

stood when considering that the effective rift-perpendicular velocity that leads to lithospheric thinning is smaller than in neighbouring, purely orthogonal rift segments (Montési and Behn, 2007). Therefore, oblique segments need more time to reach breakup. This is why final continental rupture of highly oblique examples, such as (1) the Fram Strait opening in the North Atlantic, (2) shearing between the Patagonian shelf and south Africa, (3) the separation of Tasmania and the Antarctic Cape Adare region, or (4) rifting between Greater India and west Australia postdate continental breakup in neighbouring segments by several tens of millions of years. This means that the average obliquity of an entire rift system increases after the beginning of breakup because the orthogonal segments tend to break early and do not contribute to the mean rift obliquity anymore. Since rifting typically starts slowly and accelerates prior to breakup (Brune et al., 2016), the long-lived oblique segments often witness the final, fast stages of rifting. This argument applies to the final rift stages of the South Atlantic and North Atlantic and the separation of India from Australia but it does not explain the correlation between obliquity and velocity prior to breakup of major rift segments, such as seen for Australia-Antarctica at $100 \mathrm{Ma}$ (Fig. 5) or the Gulf of California at 18 to $5 \mathrm{Ma}$ (Fig. 7). In both situations, a change in the direction of plate divergence induced higher rift obliquity and simultaneously the rift velocity increased. This might be explained by the aforementioned argument that oblique rifting requires less tectonic force, which leads to a higher rift velocity at constant extensional stress (Brune et al., 2012). We suggest that the change in extension direction sparked a significant loss in rift strength (Brune et al., 2016), which ultimately generated a speed-up of Baja California relative to North America and of Australia relative to Antarctica.

Oblique rifting is closely linked to toroidal plate motion, i.e. the spin of plates and associated strike-slip deformation. The concept of decomposing Earth's plate motions into toroidal (plate boundary parallel) and poloidal (plate boundary perpendicular) components is motivated by the insight that toroidal motion does not affect the buoyancy configuration of Earth's mantle. It is hence not directly driven by mantle convection and in a homogeneous plate-mantle system, energy consumption due to toroidal motion should therefore be minimized (O'Connell et al., 1991). Large lateral rheological contrasts within and between Earth's plates have been invoked to explain some part of the toroidal motion component (Becker, 2006; Rolf et al., 2017). However, an additional part of the toroidal plate motion might be due to rift obliquity: since oblique rifting reduces rift strength, it favours the development of oblique plate boundaries, which enhances large-scale plate rotation and associated toroidal surface velocity components. LithgowBertelloni and Richards (1993) showed that the toroidal component of plate motions slowly declined since $120 \mathrm{Ma}$, despite large variations in the poloidal component of plate velocities. Notwithstanding significant uncertainty, the ratio of toroidal to poloidal velocities appears to be especially high between 120 and $\sim 80 \mathrm{Ma}$. This period corresponds to a distinct decline in the lengths of rifts involved in Pangea breakup (Fig. 8, and Brune et al., 2017c). Hence we speculate that the toroidal to poloidal ratio could be higher during continental breakup because of the rift characteristic to favour oblique motion, a process that has less impact on plate motions once the continents become dispersed. 


\section{Conclusions}

In this study we evaluated the rift obliquity of major continent-scale rift systems by analysing a global plate tectonic reconstruction from the onset of Pangea fragmentation to the present day. We find that the classical 2-D assumption where the extension direction is perpendicular to the rift trend is not justified in most cases. Instead, the majority of rift systems leading to continental breakup during the last 230 million years involved moderate to high rift obliquity. Approximately $70 \%$ of all rift segments involved a distinct obliquity higher than $20^{\circ}$, while the global average in terms of rift obliquity is $34^{\circ}$. This high contribution of oblique deformation can be explained through the generally irregular shape of plate boundaries, possibly related to tectonic inheritance, and by the concept of obliquity-dependent plate boundary strength. Oblique deformation generates intrinsically 3-D stress and strain fields that hamper simplified tectonic interpretation via 2-D cross sections, models and seismic profiles. Our results indicate that oblique plate boundary deformation should be considered the rule and not the exception when investigating the dynamics of rifts and rifted margins.

Data availability. The data used in this study are accessible as supplementary material to previous publications: for the rotation file we refer to Müller et al. (2016) and for continent-ocean boundaries we refer to Brune et al. (2016).

Author contributions. SB and SEW conceived the plate tectonic analysis and implemented the workflow. SB, SEW, and RDM discussed and integrated the results. The paper was written by SB with contributions from all authors.

Competing interests. The authors declare that they have no conflict of interest.

Acknowledgements. This research has been funded by the German Academic Exchange Service (DAAD), project no. 57319603. Sascha Brune was supported through the Helmholtz Young Investigators Group CRYSTALS (VH-NG-1132). Simon E. Willliams and R. Dietmar Müller were supported by Australian Research Council grant IH130200012. We thank two anonymous reviewers and editor Federico Rossetti for their constructive and motivating comments that significantly helped to improve this manuscript.

The article processing charges for this open-access publication were covered by a Research

Centre of the Helmholtz Association.

Edited by: Federico Rossetti

Reviewed by: two anonymous referees

\section{References}

Agostini, A., Corti, G., Zeoli, A., and Mulugeta, G.: Evolution, pattern, and partitioning of deformation during oblique continental rifting: Inferences from lithospheric-scale centrifuge models, Geochem. Geophy. Geosy., 10, Q11015, https://doi.org/10.1029/2009GC002676, 2009.

Ali, J. R. and Aitchison, J. C.: Greater India's northern margin prior to its collision with Asia, Basin Res., 26, 73-84, https://doi.org/10.1111/bre.12040, 2014.

Allken, V., Huismans, R. S., and Thieulot, C.: Factors controlling the mode of rift interaction in brittle-ductile coupled systems: A 3D numerical study, Geochem. Geophy. Geosy., 13, Q05010, https://doi.org/10.1029/2012GC004077, 2012.

Ammann, N., Liao, J., Gerya, T., and Ball, P.: Oblique continental rifting and long transform fault formation based on 3D thermomechanical numerical modeling, Tectonophysics, in press, https://doi.org/10.1016/j.tecto.2017.08.015, 2017.

Atwater, T. and Stock, J.: Pacific-North America Plate Tectonics of the Neogene Southwestern United States: An Update, Int. Geol. Rev., 40, 375-402, https://doi.org/10.1080/00206819809465216, 1998.

Balázs, A., Matenco, L., Vogt, K., Cloetingh, S., and Gerya, T.: Extensional polarity change in continental rifts: inferences from 3D numerical modeling and observations, J. Geophys. Res.-Sol. Ea., 123, 8073-8094, https://doi.org/10.1029/2018JB015643, 2018.

Ball, P., Eagles, G., Ebinger, C., McClay, K., and Totterdell, J.: The spatial and temporal evolution of strain during the separation of Australia and Antarctica, Geochem. Geophy. Geosy., 14, 27712799, https://doi.org/10.1002/ggge.20160, 2013.

Barnett-Moore, N., Müller, D. R., Williams, S., Skogseid, J., and Seton, M.: A reconstruction of the North Atlantic since the earliest Jurassic, Basin Res., 30, 1-26, https://doi.org/10.1111/bre.12214, 2016.

Basile, C.: Transform continental margins - part 1: Concepts and models, Tectonophysics, 661, 1-10, https://doi.org/10.1016/j.tecto.2015.08.034, 2015.

Bayrakci, G., Minshull, T. A., Sawyer, D. S., Reston, T. J., Klaeschen, D., Papenberg, C., Ranero, C., Bull, J. M., Davy, R. G., Shillington, D. J., Perez-Gussinye, M., and Morgan, J. K.: Fault-controlled hydration of the upper mantle during continental rifting, Nat. Geosci., 9, 384-388, https://doi.org/10.1038/ngeo2671, 2016.

Becker, T. W.: On the effect of temperature and strain-rate dependent viscosity on global mantle flow, net rotation, and platedriving forces, Geophys. J. Int., 167, 943-957, 2006.

Bennett, S. E. K. and Oskin, M. E.: Oblique rifting ruptures continents: Example from the Gulf of California shear zone, Geology, 42, 215-218, https://doi.org/10.1130/G34904.1, 2014.

Bercovici, D.: The generation of plate tectonics from mantle convection, Earth Planet. Sc. Lett., 205, 107-121, https://doi.org/10.1016/S0012-821X(02)01009-9, 2003.

Bertrand, G., Horstmann, M., Hermann, O., and Behrmann, J. H.: Retrodeformation of the southern Upper Rhine Graben: new insights on continental oblique rifting, Quaternary Sci. Rev., 24, 345-352, https://doi.org/10.1016/j.quascirev.2004.07.011, 2005.

Bonini, M., Souriot, T., Boccaletti, M., and Brun, J. P.: Successive orthogonal and oblique extension episodes in a rift zone: Laboratory experiments with application to the Ethiopian Rift, Tectonics, 16, 347-362, https://doi.org/10.1029/96TC03935, 1997. 
Borissova, I., Coffin, M. F., Charvis, P., and Operto, S.: Structure and development of a microcontinent: Elan Bank in the southern Indian Ocean, Geochem. Geophy. Geosy., 4, 1071, https://doi.org/10.1029/2003GC000535, 2003.

Brune, S.: Evolution of stress and fault patterns in oblique rift systems: 3-D numerical lithospheric-scale experiments from rift to breakup, Geochem. Geophy. Geosy., 15, 3392-3415, https://doi.org/10.1002/2014GC005446, 2014.

Brune, S.: Rifts and rifted margins: A review of geodynamic processes and natural hazards, edited by: Duarte, J. C. and Schellart, W. P., Plate Boundaries and Natural Hazards, 219, 11-37, https://doi.org/10.1002/9781119054146.ch2, 2016.

Brune, S.: Forces within continental and oceanic rifts: Numerical modeling elucidates the impact of asthenospheric flow on surface stress, Geology, 46, 191-192, https://doi.org/10.1130/focus022018.1, 2018.

Brune, S. and Autin, J.: The rift to break-up evolution of the Gulf of Aden: Insights from 3D numerical lithospheric-scale modelling, Tectonophysics, 607, 65-79, https://doi.org/10.1016/j.tecto.2013.06.029, 2013.

Brune, S., Popov, A. A., and Sobolev, S. V.: Modeling suggests that oblique extension facilitates rifting and continental break-up, J. Geophys. Res., 117, B08402, https://doi.org/10.1029/2011JB008860, 2012.

Brune, S., Heine, C., Perez-Gussinye, M., and Sobolev, S. V.: Rift migration explains continental margin asymmetry and crustal hyper-extension, Nat. Commun., 5, https://doi.org/10.1038/ncomms5014, 2014.

Brune, S., Williams, S. E., Butterworth, N. P., and Müller, R. D.: Abrupt plate accelerations shape rifted continental margins, Nature, 536, 201-204, https://doi.org/10.1038/nature18319, 2016.

Brune, S., Heine, C., Clift, P. D., and Pérez-Gussinyé, M.: Rifted margin architecture and crustal rheology: Reviewing Iberia-Newfoundland, Central South Atlantic, and South China Sea, Mar. Petrol. Geol., 79, 257-281, https://doi.org/10.1016/j.marpetgeo.2016.10.018, 2017a.

Brune, S., Corti, G., and Ranalli, G.: Controls of inherited lithospheric heterogeneity on rift linkage: Numerical and analog models of interaction between the Kenyan and Ethiopian rifts across the Turkana depression, Tectonics, 36, 2017TC004739, https://doi.org/10.1002/2017TC004739, 2017b.

Brune, S., Williams, S. E., and Müller, R. D.: Potential links between continental rifting, $\mathrm{CO}_{2}$ degassing and climate change through time, Nat. Geosci., 10, 941-946, https://doi.org/10.1038/s41561-017-0003-6, 2017c.

Buck, W. R.: The Dynamics of Continental Breakup and Extension: Treatise on Geophysics, 2nd Edn., Vol 6 - Crust and Lithosphere Dynamics, 2015.

Burov, E. B.: Plate Rheology and Mechanics: Treatise on Geophysics, 2nd Edn., edited by: Schubert, G., 95-152, https://doi.org/10.1016/B978-0-444-53802-4.00112-3, 2015.

Chaboureau, A.-C., Guillocheau, F., Robin, C., Rohais, S., Moulin, M., and Aslanian, D.: Paleogeographic evolution of the central segment of the South Atlantic during Early Cretaceous times: Paleotopographic and geodynamic implications, Tectonophysics, 604, 191-223, https://doi.org/10.1016/j.tecto.2012.08.025, 2013.

Clifton, A. E. and Schlische, R. W.: Nucleation, growth, and linkage of faults in oblique rift zones: Results from experimental clay models and implications for maximum fault size, Geology, 29, 455-458, https://doi.org/10.1130/00917613(2001)029<0455:NGALOF>2.0.CO;2, 2001.

Clifton, A. E., Schlische, R. W., Withjack, M. O., and Ackermann, R. V.: Influence of rift obliquity on fault-population systematics: results of experimental clay models, J. Struct. Geol., 22, 14911509, https://doi.org/10.1016/S0191-8141(00)00043-2, 2000.

Coffin, M. F. and Eldholm, O.: Volcanism and continental break-up: a global compilation of large igneous provinces, Geol. Soc. Spec. Publ., 68, 17-30, https://doi.org/10.1144/GSL.SP.1992.068.01.02, 1992.

Corti, G.: Control of rift obliquity on the evolution and segmentation of the main Ethiopian rift, Nat. Geosci., 1, 258-262, https://doi.org/10.1038/ngeo160, 2008.

Daly, M. C., Chorowicz, J., and Fairhead, J. D.: Rift basin evolution in Africa: the influence of reactivated steep basement shear zones, Geol. Soc. Spec. Publ., 44, 309-334, https://doi.org/10.1144/GSL.SP.1989.044.01.17, 1989.

Darin, M. H., Bennett, S. E. K., Dorsey, R. J., Oskin, M. E., and Iriondo, A.: Late Miocene extension in coastal Sonora, México: Implications for the evolution of dextral shear in the protoGulf of California oblique rift, Tectonophysics, 693, 378-408, https://doi.org/10.1016/j.tecto.2016.04.038, 2016.

Davis, J. K., Lawver, L. A., Norton, I. O., and Gahagan, L. M.: New Somali Basin magnetic anomalies and a plate model for the early Indian Ocean, Gondwana Res., 34, 16-28, https://doi.org/10.1016/j.gr.2016.02.010, 2016.

Deng, C., Gawthorpe, R., Fossen, H., and Finch, E.: How does the orientation of a pre-existing basement weakness influence fault development during renewed rifting? Insights from threedimensional discrete element modeling, Tectonics, 37, 22212242, https://doi.org/10.1029/2017TC004776, 2018.

Dewey, J. F., Holdsworth, R. E., and Strachan, R. A.: Transpression and transtension zones, Geol. Soc. Spec. Publ., 135, 1-14, https://doi.org/10.1144/GSL.SP.1998.135.01.01, 1998.

de Wit, M. J., Stankiewicz, J., and Reeves, C.: Restoring PanAfrican-Brasiliano connections: more Gondwana control, less Trans-Atlantic corruption, Geol. Soc. Spec. Publ., 294, 399-412, 2008.

Díaz-Azpiroz, M., Brune, S., Leever, K. A., Fernández, C., and Czeck, D. M.: Tectonics of oblique plate boundary systems, Tectonophysics, 693, 165-170, https://doi.org/10.1016/j.tecto.2016.07.028, 2016.

Dickie, K., Keen, C. E., Williams, G. L., and Dehler, S. A.: Tectonostratigraphic evolution of the Labrador margin, Atlantic Canada, Mar. Petrol. Geol., 28, 1663-1675, https://doi.org/10.1016/j.marpetgeo.2011.05.009, 2011.

Doré, A. G.: The structural foundation and evolution of Mesozoic seaways between Europe and the Arctic, Palaeogeogr. Palaeocl., 87, 441-492, https://doi.org/10.1016/0031-0182(91)90144-G, 1991.

Duque-Trujillo, J., Ferrari, L., Orozco-Esquivel, T., LópezMartínez, M., Lonsdale, P., Bryan, S. E., Kluesner, J., PiñeroLajas, D., and Solari, L.: Timing of rifting in the southern Gulf of California and its conjugate margins: Insights from the plutonic record, Geol. Soc. Am. Bull., 127, 702-736, https://doi.org/10.1130/B31008.1, 2015.

Espurt, N., Callot, J.-P., Roure, F., Totterdell, J. M., Struckmeyer, H. I. M., and Vially, R.: Transition from symmetry to asymmetry during continental rifting: an example from the Bight 
Basin-Terre Adélie (Australian and Antarctic conjugate margins), Terra Nova, 24, 167-180, https://doi.org/10.1111/j.13653121.2011.01055.x, 2012.

Faleide, J. I., Tsikalas, F., Breivik, A. J., Mjelde, R., Ritzmann, O., Engen, O., Wilson, J., and Eldholm, O.: Structure and Evolution of the Continental Margin off Norway and the Barents Sea, Episodes, 31, 82-91, 2008.

Féraud, G., Beslier, M.-O., and Cornen, G.: 40Ar/39Ar dating of gabbros from the ocean/continent transition of the western Iberia Margin: Preliminary results: Proceedings of the Ocean Drilling Program, Scientific Results, 149, 489-495, 1996.

Ferrari, L., López-Martínez, M., Orozco-Esquivel, T., Bryan, S. E., Duque-Trujillo, J., Lonsdale, P., and Solari, L.: Late Oligocene to Middle Miocene rifting and synextensional magmatism in the southwestern Sierra Madre Occidental, Mexico: The beginning of the Gulf of California rift, Geosphere, 9, 1161-1200, https://doi.org/10.1130/GES00925.1, 2013.

Fletcher, J. M., Grove, M., Kimbrough, D., Lovera, O., and Gehrels, G. E.: Ridge-trench interactions and the Neogene tectonic evolution of the Magdalena shelf and southern Gulf of California: Insights from detrital zircon $\mathrm{U}-\mathrm{Pb}$ ages from the Magdalena fan and adjacent areas, Geol. Soc. Am. Bull., 119, 1313-1336, https://doi.org/10.1130/B26067.1, 2007.

Fossen, H. and Rotevatn, A.: Fault linkage and relay structures in extensional settings - A review, Earth-Sci. Rev., 154, 14-28, https://doi.org/10.1016/j.earscirev.2015.11.014, 2016.

Fournier, M. and Petit, C.: Oblique rifting at oceanic ridges: Relationship between spreading and stretching directions from earthquake focal mechanisms, J. Struct. Geol., 29, 201-208, https://doi.org/10.1016/j.jsg.2006.07.017, 2007.

Fournier, M., Bellahsen, N., Fabbri, O., and Gunnell, Y.: Oblique rifting and segmentation of the NE Gulf of Aden passive margin, Geochem. Geophy. Geosy., 5, Q11005, https://doi.org/10.1029/2004GC000731, 2004.

Gaina, C., Nasuti, A., Kimbell, G. S., and Blischke, A.: Break-up and seafloor spreading domains in the NE Atlantic, Geol. Soc. Spec. Publ., 447, SP447.12, https://doi.org/10.1144/SP447.12, 2017.

Gawthorpe, R. L. and Leeder, M. R.: Tectono-sedimentary evolution of active extensional basins, Basin Res., 12, 195-218, 2000.

Gernigon, L., Blischke, A., Nasuti, A., and Sand, M.: Conjugate volcanic rifted margins, seafloor spreading, and microcontinent: Insights from new high-resolution aeromagnetic surveys in the Norway Basin, Tectonics, 34, 2014TC003717, https://doi.org/10.1002/2014TC003717, 2015.

Gerya, T. V.: Initiation of transform faults at rifted continental margins: 3D petrological-thermomechanical modeling and comparison to the Woodlark Basin, Petrology, 21, 550-560, https://doi.org/10.1134/S0869591113060039, 2013.

Gibbons, A. D., Whittaker, J. M., and Müller, R. D.: The breakup of East Gondwana: Assimilating constraints from Cretaceous ocean basins around India into a best-fit tectonic model, J. Geophys. Res.-Sol. Ea., 118, 808-822, https://doi.org/10.1002/jgrb.50079, 2013.

Gibbons, A. D., Zahirovic, S., Müller, R. D., Whittaker, J. M., and Yatheesh, V.: A tectonic model reconciling evidence for the collisions between India, Eurasia and intra-oceanic arcs of the central-eastern Tethys, Gondwana Res., 28, 451-492, https://doi.org/10.1016/j.gr.2015.01.001, 2015.
Gillard, M., Autin, J., Manatschal, G., Sauter, D., Munschy, M., and Schaming, M.: Tectonomagmatic evolution of the final stages of rifting along the deep conjugate Australian-Antarctic magma-poor rifted margins: Constraints from seismic observations, Tectonics, 34, 2015TC003850, https://doi.org/10.1002/2015TC003850, 2015.

Gillard, M., Autin, J., and Manatschal, G.: Fault systems at hyperextended rifted margins and embryonic oceanic crust: Structural style, evolution and relation to magma, Mar. Petrol. Geol., 76, 51-67, https://doi.org/10.1016/j.marpetgeo.2016.05.013, 2016.

Granot, R. and Dyment, J.: The Cretaceous opening of the South Atlantic Ocean, Earth Planet. Sc. Lett., 414, 156-163, https://doi.org/10.1016/j.epsl.2015.01.015, 2015.

Granot, R. and Dyment, J.: Late Cenozoic unification of East and West Antarctica, Nat. Commun., 9, 3189, https://doi.org/10.1038/s41467-018-05270-w, 2018.

Heine, C. and Brune, S.: Oblique rifting of the Equatorial Atlantic: Why there is no Saharan Atlantic Ocean, Geology, 42, 211-214, https://doi.org/10.1130/G35082.1, 2014.

Heine, C., Zoethout, J., and Müller, R. D.: Kinematics of the South Atlantic rift, Solid Earth, 4, 215-253, https://doi.org/10.5194/se4-215-2013, 2013.

Hetzel, R. and Strecker, M. R.: Late Mozambique Belt structures in western Kenya and their influence on the evolution of the Cenozoic Kenya Rift, J. Struct. Geol., 16, 189-201, https://doi.org/10.1016/0191-8141(94)90104-X, 1994.

Hodge, M. S., Fagereng, Å., Biggs, J., and Mdala, H.: Controls on early-rift geometry: new perspectives from the BililaMtakataka fault, Malawi, Geophys. Res. Lett., 45, 3896-3905, https://doi.org/10.1029/2018GL077343, 2018.

Hosseinpour, M., Müller, R. D., Williams, S. E., and Whittaker, J. M.: Full-fit reconstruction of the Labrador Sea and Baffin Bay, Solid Earth, 4, 461-479, https://doi.org/10.5194/se-4-461-2013, 2013.

Huismans, R. S. and Beaumont, C.: Depth-dependent extension, two-stage breakup and cratonic underplating at rifted margins, Nature, 473, 74-78, https://doi.org/10.1038/nature09988, 2011.

Jakobsson, M., Backman, J., Rudels, B., Nycander, J., Frank, M., Mayer, L., Jokat, W., Sangiorgi, F., O’Regan, M., Brinkhuis, H., King, J., and Moran, K.: The early Miocene onset of a ventilated circulation regime in the Arctic Ocean, Nature, 447, 986-990, https://doi.org/10.1038/nature05924, 2007.

Jeanniot, L. and Buiter, S. J. H.: A quantitative analysis of transtensional margin width, Earth Planet. Sc. Lett., 491, 95-108, https://doi.org/10.1016/j.eps1.2018.03.003, 2018.

Klimke, J. and Franke, D.: Gondwana breakup: no evidence for a Davie Fracture Zone offshore northern Mozambique, Tanzania and Kenya, Terra Nova, 28, 233-244, https://doi.org/10.1111/ter.12214, 2016.

Kneller, E. A., Johnson, C. A., Karner, G. D., Einhorn, J., and Queffelec, T. A.: Inverse methods for modeling non-rigid plate kinematics: Application to mesozoic plate reconstructions of the Central Atlantic, Comput. Geosci., 49, 217-230, https://doi.org/10.1016/j.cageo.2012.06.019, 2012.

Knies, J. and Gaina, C.: Middle Miocene ice sheet expansion in the Arctic: Views from the Barents Sea, Geochem. Geophy. Geosy., 9, Q02015, https://doi.org/10.1029/2007GC001824, 2008. 
Kröner, A. and Stern, R. J.: Pan-African Orogeny, Encyclopedia of Geology, edited by: Selley, R. C., Cocks, L. R. M., and Plimer, I. R., 1-12, Elsevier, Oxford, 2005.

Lavier, L. L. and Manatschal, G.: A mechanism to thin the continental lithosphere at magma-poor margins, Nature, 440, 324-328, https://doi.org/10.1038/nature04608, 2006.

Le Calvez, J. H. and Vendeville, B. C.: Experimental designs to model along-strike fault interaction, Journal of the Virtual Explorer, 7, 1-17, https://doi.org/10.3809/jvirtex.2002.00043, 2002.

Le Pourhiet, L., Huet, B., May, D. A., Labrousse, L., and Jolivet, L.: Kinematic interpretation of the 3D shapes of metamorphic core complexes: Geochem. Geophy. Geosy., 13, Q09002, https://doi.org/10.1029/2012GC004271, 2012.

Le Pourhiet, L., May, D. A., Huille, L., Watremez, L., and Leroy, S.: A genetic link between transform and hyperextended margins, Earth Planet. Sc. Lett., 465, 184-192, https://doi.org/10.1016/j.epsl.2017.02.043, 2017.

Lithgow-Bertelloni, C., Richards, M. A., Ricard, Y., O'Connell, R. J., and Engebretson, D. C.: Toroidal-poloidal partitioning of plate motions since 120 MA, Geophys. Res. Lett., 20, 375-378, https://doi.org/10.1029/93GL00168, 1993.

Lizarralde, D., Axen, G. J., Brown, H. E., Fletcher, J. M., GonzalezFernandez, A., Harding, A. J., Holbrook, W. S., Kent, G. M., Paramo, P., Sutherland, F., and Umhoefer, P. J.: Variation in styles of rifting in the Gulf of California, Nature, 448, 466-469, https://doi.org/10.1038/nature06035, 2007.

Lundin, E. R. and Doré, A. G.: A tectonic model for the Norwegian passive margin with implications for the NE Atlantic: Early Cretaceous to break-up, J. Geol. Soc. London, 154, 545-550, https://doi.org/10.1144/gsjgs.154.3.0545, 1997.

Manatschal, G., Lavier, L., and Chenin, P.: The role of inheritance in structuring hyperextended rift systems: Some considerations based on observations and numerical modeling, Gondwana Res., 27, 140-164, https://doi.org/10.1016/j.gr.2014.08.006, 2015.

Mart, Y., Ryan, W. B. F., and Lunina, O. V.: Review of the tectonics of the Levant Rift system: the structural significance of oblique continental breakup, Tectonophysics, 395, 209-232, https://doi.org/10.1016/j.tecto.2004.09.007, 2005.

McKenzie, D.: Some remarks on the development of sedimentary basins, Earth Planet. Sc. Lett., 40, 25-32, https://doi.org/10.1016/0012-821X(78)90071-7, 1978.

McQuarrie, N. and Wernicke, B. P.: An animated tectonic reconstruction of southwestern North America since $36 \mathrm{Ma}$, Geosphere, 1, 147-172, https://doi.org/10.1130/GES00016.1, 2005.

Mericer de Lépinay, M., Loncke, L., Basile, C., Roest, W. R., Patriat, M., Maillard, A., and De Clarens, P.: Transform continental margins - Part 2: A worldwide review, Tectonophysics, 693, 96115, https://doi.org/10.1016/j.tecto.2016.05.038, 2016.

Molnar, N. E., Cruden, A. R., and Betts, P. G.: Interactions between propagating rotational rifts and linear rheological heterogeneities: Insights from three-dimensional laboratory experiments, Tectonics, 36, 2016TC004447, https://doi.org/10.1002/2016TC004447, 2017.

Mondy, L. S., Rey, P. F., Duclaux, G., and Moresi, L.: The role of asthenospheric flow during rift propagation and breakup, Geology, 46, 103-106, https://doi.org/10.1130/G39674.1, 2017.
Montési, L. G. J. and Behn, M. D.: Mantle flow and melting underneath oblique and ultraslow mid-ocean ridges, Geophys. Res. Lett., 34, L24307, https://doi.org/10.1029/2007GL031067, 2007.

Morley, C. K.: The impact of multiple extension events, stress rotation and inherited fabrics on normal fault geometries and evolution in the Cenozoic rift basins of Thailand, Geol. Soc. Spec. Publ., 439, SP439.3, https://doi.org/10.1144/SP439.3, 2016.

Moulin, M., Aslanian, D., and Unternehr, P.: A new starting point for the South and Equatorial Atlantic Ocean, Earth-Sci. Rev., 98, 1-37, https://doi.org/10.1016/j.earscirev.2009.08.001, 2010.

Müller, R. D., Seton, M., Zahirovic, S., Williams, S. E., Matthews, K. J., Wright, N. M., Shephard, G. E., Maloney, K. T., BarnettMoore, N., Hosseinpour, M., Bower, D. J., and Cannon, J.: Ocean Basin Evolution and Global-Scale Plate Reorganization Events Since Pangea Breakup, Annu. Rev. Earth Pl. Sc., 44, 107-138, https://doi.org/10.1146/annurev-earth-060115-012211, 2016.

Müller, R. D., Cannon, J., Qin, X., Watson, R. J., Gurnis, M., Williams, S., Pfaffelmoser, T., Seton, M., Russell, S. H. J., and Zahirovic, S.: GPlates - Building a Virtual Earth Through Deep Time, Geochem. Geophy. Geosy., 2243-2261, https://doi.org/10.1029/2018GC007584, 2018.

Naliboff, J. B., Buiter, S. J. H., Péron-Pinvidic, G., Osmundsen, P. T., and Tetreault, J.: Complex fault interaction controls continental rifting, Nat. Commun., 8, 1179, https://doi.org/10.1038/s41467-017-00904-x, 2017.

Nemčok, M., Sinha, S. T., Doré, A. G., Lundin, E. R., Mascle, J., and Rybár, S.: Mechanisms of microcontinent release associated with wrenching-involved continental breakup; a review, Geol. Soc. Spec. Publ., 431, SP431.14, https://doi.org/10.1144/SP431.14, 2016.

Nirrengarten, M., Manatschal, G., Tugend, J., Kusznir, N., and Sauter, D.: Kinematic Evolution of the Southern North Atlantic: Implications for the Formation of Hyperextended Rift Systems, Tectonics, 37, 89-118, https://doi.org/10.1002/2017TC004495, 2018.

Norvick, M. S. and Smith, M. A.: Mapping the plate tectonic reconstruction of southern and southeastern Australia and implications for petroleum systems, The APPEA Journal, 41, 15-35, https://doi.org/10.1071/aj00001, 2001.

Nürnberg, D. and Müller, R. D.: The Tectonic Evolution of the South-Atlantic from Late Jurassic to Present, Tectonophysics, 191, 27-53, https://doi.org/10.1016/0040-1951(91)90231-G, 1991.

O'Connell, R. J., Gable, C. W., and Hager, B. H.: Toroidal-Poloidal Partitioning of Lithospheric Plate Motions, NATO Ad. Sci. I. C.Mat., 535-551, https://doi.org/10.1007/978-94-011-3374-6_25, 1991.

Oskin, M. and Stock, J.: Marine incursion synchronous with plate-boundary localization in the Gulf of California, Geology, 31, 23-26, https://doi.org/10.1130/00917613(2003)031<0023:MISWPB>2.0.CO;2, 2003.

Osmundsen, P. T. and Redfield, T. F.: Crustal taper and topography at passive continental margins, Terra Nova, 23, 349-361, https://doi.org/10.1111/j.1365-3121.2011.01014.x, 2011.

Peron-Pinvidic, G., Manatschal, G., and Osmundsen, P. T.: Structural comparison of archetypal Atlantic rifted margins: A review of observations and concepts, Mar. Petrol. Geol., 43, 21-47, https://doi.org/10.1016/j.marpetgeo.2013.02.002, 2013. 
Phethean, J. J. J., Kalnins, L. M., van Hunen, J., Biffi, P. G., Davies, R. J., and McCaffrey, K. J. W.: Madagascar's escape from Africa: A high-resolution plate reconstruction for the Western Somali Basin and implications for supercontinent dispersal, Geochem. Geophy. Geosy., 17, 5036-5055, https://doi.org/10.1002/2016GC006624, 2016.

Philippon, M. and Corti, G.: Obliquity along plate boundaries, Tectonophysics, 693B, 171-182, https://doi.org/10.1016/j.tecto.2016.05.033, 2016.

Philippon, M., Willingshofer, E., Sokoutis, D., Corti, G., Sani, F., Bonini, M., and Cloetingh, S.: Slip re-orientation in oblique rifts, Geology, 43, 147-150, https://doi.org/10.1130/G36208.1, 2015.

Phillips, T. B., Jackson, C. A.-L., Bell, R. E., and Duffy, O. B.: Oblique reactivation of lithosphere-scale lineaments controls rift physiography - the upper-crustal expression of the SorgenfreiTornquist Zone, offshore southern Norway, Solid Earth, 9, 403429, https://doi.org/10.5194/se-9-403-2018, 2018.

Powell, C. M., Roots, S. R., and Veevers, J. J.: Pre-breakup continental extension in East Gondwanaland and the early opening of the eastern Indian Ocean, Tectonophysics, 155, 261-283, https://doi.org/10.1016/0040-1951(88)90269-7, 1988.

Power, M. R., Hill, K. C., Hoffman, N., Bernecker, T., and Norvick, M.: The Structural and Tectonic Evolution of the Gippsland Basin: Results from 2D Section Balancing and 3D Structural Modelling, available at: http://archives.datapages.com/data/ petroleum-exploration-society-of-australia/conferences/001/ 001001/pdfs/373.htm (last access: June 2018), 2001.

Quirk, D. G., Hertle, M., Jeppesen, J. W., Raven, M., Mohriak, W. U., Kann, D. J., Nørgaard, M., Howe, M. J., Hsu, D., Coffey, B., and Mendes, M. P.: Rifting, subsidence and continental break-up above a mantle plume in the central South Atlantic, Geol. Soc. Spec. Publ., 369, 185-214, https://doi.org/10.1144/SP369.20, 2013

Ranero, C. R. and Pérez-Gussinyé, M.: Sequential faulting explains the asymmetry and extension discrepancy of conjugate margins, Nature, 468, 294-299, https://doi.org/10.1038/nature09520, 2010.

Rolf, T., Capitanio, F. A., and Tackley, P. J.: Constraints on mantle viscosity structure from continental drift histories in spherical mantle convection models, Tectonophysics, in press, https://doi.org/10.1016/j.tecto.2017.04.031, 2017.

Rossetti, F., Lisker, F., Storti, F., and Läufer, A. L.: Tectonic and denudational history of the Rennick Graben (North Victoria Land): Implications for the evolution of rifting between East and West Antarctica, Tectonics, 22, 1016, https://doi.org/10.1029/2002TC001416, 2003.

Royer, J.-Y. and Sandwell, D. T.: Evolution of the eastern Indian Ocean since the Late Cretaceous: Constraints from Geosat altimetry, J. Geophys. Res.-Sol. Ea., 94, 13755-13782, https://doi.org/10.1029/JB094iB10p13755, 1989.

Sanderson, D. J. and Marchini, W. R. D.: Transpression, J. Struct. Geol., 6, 449-458, https://doi.org/10.1016/01918141(84)90058-0, 1984

Schreurs, G. and Colletta, B.: Analogue modelling of faulting in zones of continental transpression and transtension, Geol. Soc. Spec. Publ., 135, 59-79, 1998.

Sippel, J., Meeßen, C., Cacace, M., Mechie, J., Fishwick, S., Heine, C., Scheck-Wenderoth, M., and Strecker, M. R.: The Kenya rift revisited: insights into lithospheric strength through data- driven 3-D gravity and thermal modelling, Solid Earth, 8, 45-81, https://doi.org/10.5194/se-8-45-2017, 2017.

Skogseid, J., Planke, S., Faleide, J. I., Pedersen, T., Eldholm, O., and Neverdal, F.: NE Atlantic continental rifting and volcanic margin formation: Geol. Soc. Spec. Publ., 167, 295-326, https://doi.org/10.1144/GSL.SP.2000.167.01.12, 2000.

Storey, M., Duncan, R. A., and Tegner, C.: Timing and duration of volcanism in the North Atlantic Igneous Province: Implications for geodynamics and links to the Iceland hotspot, Chem. Geol., 241, 264-281, https://doi.org/10.1016/j.chemgeo.2007.01.016, 2007.

Teyssier, C., Tikoff, B., and Markley, M.: Oblique plate motion and continental tectonics, Geology, 23, 447-450, https://doi.org/10.1130/00917613(1995)023<0447:OPMACT>2.3.CO;2, 1995.

Tikku, A. A. and Cande, S. C.: The oldest magnetic anomalies in the Australian-Antarctic Basin: Are they isochrons?, J. Geophys. Res.-Sol. Ea., 104, 661-677, https://doi.org/10.1029/1998JB900034, 1999.

Torsvik, T. H., Rousse, S., Labails, C., and Smethurst, M. A.: A new scheme for the opening of the South Atlantic Ocean and the dissection of an Aptian salt basin, Geophys. J. Int., 177, 13151333, 2009.

Tron, V. and Brun, J.-P.: Experiments on oblique rifting in brittle-ductile systems, Tectonophysics, 188, 71-84, https://doi.org/10.1016/0040-1951(91)90315-J, 1991.

Tugend, J., Manatschal, G., Kusznir, N. J., Masini, E., Mohn, G., and Thinon, I.: Formation and deformation of hyperextended rift systems: Insights from rift domain mapping in the Bay of Biscay-Pyrenees, Tectonics, 33, 2014TC003529, https://doi.org/10.1002/2014TC003529, 2014.

Umhoefer, P. J.: Why did the Southern Gulf of California rupture so rapidly? - Oblique divergence across hot, weak lithosphere along a tectonically active margin, GSA Today, 21, 4-10, https://doi.org/10.1130/G133A.1, 2011.

Umhoefer, P. J., Darin, M. H., Bennett, S. E. K., Skinner, L. A., Dorsey, R. J., and Oskin, M. E.: Breaching of strike-slip faults and successive flooding of pull-apart basins to form the Gulf of California seaway from ca. 8-6 Ma, Geology, 46, 695-698, https://doi.org/10.1130/G40242.1, 2018.

Vignaroli, G., Balsamo, F., Giordano, G., Rossetti, F., and Storti, F.: Miocene-to-Quaternary oblique rifting signature in the Western Ross Sea from fault patterns in the McMurdo Volcanic Group, north Victoria Land, Antarctica, Tectonophysics, 656, 74-90, https://doi.org/10.1016/j.tecto.2015.05.027, 2015.

White, N.: Recovery of strain rate variation from inversion of subsidence data, Nature, 366, 449-452, https://doi.org/10.1038/366449a0, 1993.

Whittaker, J. M., Williams, S. E., and Müller, R. D.: Revised tectonic evolution of the Eastern Indian Ocean, Geochem. Geophy. Geosy., 14, 1891-1909, https://doi.org/10.1002/ggge.20120, 2013.

Whittaker, J. M., Williams, S. E., Halpin, J. A., Wild, T. J., Stilwell, J. D., Jourdan, F., and Daczko, N. R.: Eastern Indian Ocean microcontinent formation driven by plate motion changes, Earth Planet. Sc. Lett., 454, 203-212, https://doi.org/10.1016/j.epsl.2016.09.019, 2016.

van Wijk, J., Axen, G., and Abera, R.: Initiation, evolution and extinction of pull-apart basins: Implications for opening 
of the Gulf of California, Tectonophysics, 719-720, 37-50, https://doi.org/10.1016/j.tecto.2017.04.019, 2017.

van Wijk, J. W.: Role of weak zone orientation in continental lithosphere extension, Geophys. Res. Lett., 32, L02303, https://doi.org/10.1029/2004GL022192, 2005.

Willcox, J. B. and Stagg, H. M. J.: Australia's southern margin: a product of oblique extension, Tectonophysics, 173, 269-281, https://doi.org/10.1016/0040-1951(90)90223-U, 1990.

Williams, S. E., Whittaker, J. M., and Müller, R. D.: Full-fit, palinspastic reconstruction of the conjugate Australian-Antarctic margins, Tectonics, 30, TC6012, https://doi.org/10.1029/2011TC002912, 2011.

Williams, S. E., Whittaker, J. M., Granot, R., and Müller, D. R.: Early India-Australia spreading history revealed by newly detected Mesozoic magnetic anomalies in the Perth Abyssal Plain, J. Geophys. Res.-Sol. Ea., 118, 3275-3284, https://doi.org/10.1002/jgrb.50239, 2013.

Williams, S. E., Whittaker, J. M., Halpin, J. A., and Müller, R. D.: Australian-Antarctic break up and seafloor spreading: Balancing geological and geophysical constraints, Earth-Sci. Rev., in press, https://doi.org/10.1016/j.earscirev.2018.10.011, 2018.
Withjack, M. O. and Jamison, W. R.: Deformation produced by oblique rifting, Tectonophysics, 126, 99-124, https://doi.org/10.1016/0040-1951(86)90222-2, 1986.

Woodcock, N. H.: The Role of Strike-Slip Fault Systems at Plate Boundaries, Philos. T. R. Soc. Lond., 317, 13-29, 1986.

Zwaan, F. and Schreurs, G.: How oblique extension and structural inheritance influence rift segment interaction: Insights from 4D analog models, Interpretation, SD119-SD138, https://doi.org/10.1190/INT-2016-0063.1, 2017.

Zwaan, F., Schreurs, G., Naliboff, J., and Buiter, S. J. H.: Insights into the effects of oblique extension on continental rift interaction from 3D analogue and numerical models, Tectonophysics, 693B, 239-260, https://doi.org/10.1016/j.tecto.2016.02.036, 2016. 